\title{
Petrography and geochemistry of the Middle Miocene Gebel El Rusas sandstones, Eastern Desert, Egypt: Implications for provenance and tectonic setting
}

\author{
SAMIR M ZAID \\ Geology Department, Faculty of Sciences, Zagazig University, 44511 Zagazig, Egypt. \\ e-mail: Samir_zaid75@yahoo.com
}

MS received 28 September 2016; revised 6 April 2017; accepted 11 April 2017; published online 9 October 2017

Petrography and bulk rock geochemistry of the Middle Miocene sandstones of the lower and upper members of Gebel El Rusas Formation along the Egyptian Red Sea Coastal plain, have been investigated to determine the provenance, tectonic setting, and weathering condition of this formation. The Lower Member is formed mainly of sandstones and conglomerates with clay interbeds. The Upper Member is more calcareous and formed mainly of sandstones and limestones with marls and clays intercalations. Petrographically, the Lower Member sandstones are mostly immature and classified as arkoses with an average framework composition of $\mathrm{Q}_{66} \mathrm{~F}_{29} \mathrm{R}_{5}$, and the Upper Member sandstones are partly submature (more quartzose, less feldspathic) and classified as subarkoses with an average framework composition of $\mathrm{Q}_{80} \mathrm{~F}_{17} \mathrm{R}_{3}$. The Gebel El Rusas sandstones are enriched in $\mathrm{Sr}, \mathrm{Ba}, \mathrm{Zr}$ and $\mathrm{Rb}$ and depleted in Co and $\mathrm{U}$, as compared to UCC. The chemical index of alteration (CIA) values suggest moderate weathering conditions. The geochemistry results revealed that the Gebel El Rusas sandstones were derived from felsic-granitic source rocks and deposited in a passive margin of a synrift basin. The inferred tectonic setting for Middle Miocene Gebel El Rusas sandstones in the study area is consistent with the regional geology of the Eastern Desert of Egypt during Middle Miocene.

Keywords. Provenance; Gebel El Rusas sandstones; Eastern Desert.

\section{Introduction}

The geochemical composition of clastic sediments has been widely used to infer provenance (Armstrong-Altrin et al. 2015b; Migani et al. 2015; Odoma et al. 2015; Zaid 2016), to evaluate the weathering history of the source area (Rahman et al. 2014; Tawfik et al. 2015), and to infer the tectonic environment (Armstrong-Altrin et al. 2015b; Etemad-Saeed et al. 2015a, b; Verma et al. 2015). The composition of clastic sediments is controlled by several factors, which include the nature of source rock, the extent of weathering, transportation and diagenesis (McLennan et al. 1993). However, the tectonic setting of the sedimentary basin may play a predominant part over other factors, because different tectonic settings can provide different kinds of source materials with variable chemical signatures (Bhatia 1983; Bhatia and Crook 1986).

The investigated area extends along the Egyptian Red Sea coastal plain in Central Eastern Desert (figure 1). The plain is covered mainly with Miocene deposits. Two stratigraphic successions 

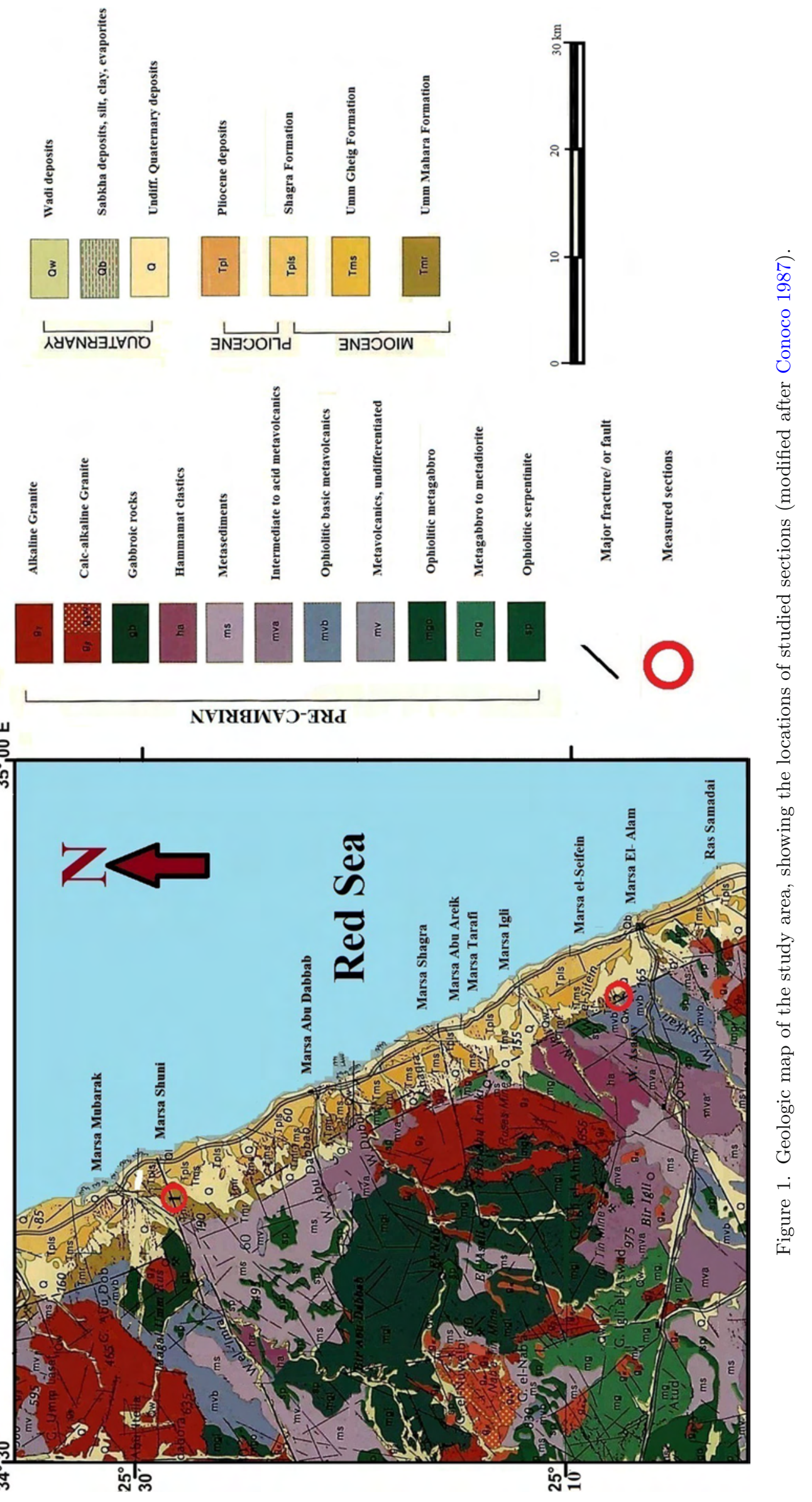
are measured and studied in detail at the Wadi Asalay-Marsa Seifein area and Wadi Shuni-Marsa Shuni area (figure 2).

The sediments of the Middle Miocene Gebel El Rusas Formation were deposited during the initiation of rifting of the Red Sea and can provide important information of the basin opening. However, these sediments have not been fully studied by geologists, except for a few ones, which included regional geology, stratigraphy and/or sedimentology (e.g., El-Akkad and Dardir 1966; Said 1990; Kora and Abdel-Fattah 2000; Zaid 2002; Issawi et al. 2009). Moreover, there are no studies available on the petrography and geochemistry. Similarly, there are no studies that focused on provenance, tectonic setting and paleoweathering of the Gebel El Rusas Formation. The main purpose of this study is to evaluate the major and trace element geochemistry of the Middle Miocene sandstones of the Gebel El Rusas Formation from two exposed sections (Wadi Asalay and Wadi Shuni, figure 1) in north Marsa Alam, Red Sea, Egypt, in order to infer their provenance, tectonic setting and weathering signatures.

\section{Geological setting}

The coastal plain strip of the Red Sea consists of two main groups: Precambrian basement Complex and the sedimentary cover (figure 1). The precambrian basement complex consists mainly of older granites, younger granites, gabbros, Hammamat clastics, metasediments, metavolcanics, metagabbro and ophiolites. On the other hand, the sedimentary cover embraces sedimentary rocks of Miocene-Quaternary age. It lies unconformably on the basement complex (El-Akkad and Dardir 1966).

The Miocene sediments are divided from older to younger into Gebel El Rusas, Abu Dabbab and Samh formations. The Gebel El Rusas Formation rests unconformably on the peneplained surface of the igneous and metamorphic rocks of the basement. The Formation underlies conformably the Miocene evaporite deposits of the Abu Dabbab Formation. The Gebel El Rusas Formation has a restricted distribution in the studied area. It is exposed in the south at the plain west of Marsa Seifein, where it caps isolated hills belonging to the basement rocks. It extends northward to Wadi Shuni, where it pinches out and the Abu Dabbab Formation is found overlying directly on the crystalline rocks as amended later by El-Akkad and Dardir (1966) and Said (1990), and accepted by Issawi et al. (2009).

The Middle Miocene Gebel El Rusas Formation consists of two members. The Lower Member is typically irregularly bedded, poorly sorted and heterogeneous. Conglomerates are common with fresh and partly weathered feldspars. A conglomerate bed of large granitic boulders, attaining $50 \mathrm{~cm}$ in diameter, separates this member from the underlying basement rocks. The Lower Member consists mainly of sandstones and conglomerates with clay interbeds. The sandstones are varicoloured and enriched with feldspar gains. The Upper Member is more calcareous than the lower member. It is formed mainly of sandstones and limestones with marls and clays intercalations. Its base is marked by a thin bed of coarse grained sandstones with poorly preserved casts. This bed is sometimes mineralised (Kora and Abdel-Fattah 2000). Gebel El Rusas Formation is generally poor in macrofauna. The only macrofauna found is poorly preserved casts of bivalves and gastropods (El-Akkad and Dardir 1966). Gebel El Rusas Formation is thinning upward, its thickness decreases from $36 \mathrm{~m}$, at Wadi Asalay, to $24 \mathrm{~m}$, at Wadi Shuni. In Wadi Asalay, it is made up mainly of sandstones alternating with limestone, conglomerates and marl beds. At Wadi Shuni, this rock unit is composed of sandstone and conglomerate with a few marl and limestone beds near the top of the formation. The composition of this formation refers to shallow marine conditions (Kora and Abdel-Fattah 2000).

The Red Sea lies between the African and Arabian plates and is essentially a product of their divergence. The distribution and disposition of the sediments along the coastal strip of the Red Sea seem to indicate that the rifting of the north Red Sea started immediately after the deposition of the Lower Eocene strata and has continued with episodic intensity since that time (Said 1990). The structural pattern of the Neogene rift is clearly inherited from the basement tectonics. The synrift sedimentation more or less begins with the Middle Miocene (Purser and Philobbos 1993). The pre-rift and proto-rift sedimentary cover is not recorded along the measured sections of the study area. The synrift rock units include the Miocene Gebel El Rusas, Abu Dabbab and Samh formations, in addition to the post-Miocene sediments.

By Middle Miocene time, the Tethys arm, which had covered the Gulf of Suez since Early Miocene time, overflowed into the Red Sea basin (Said 1990) 


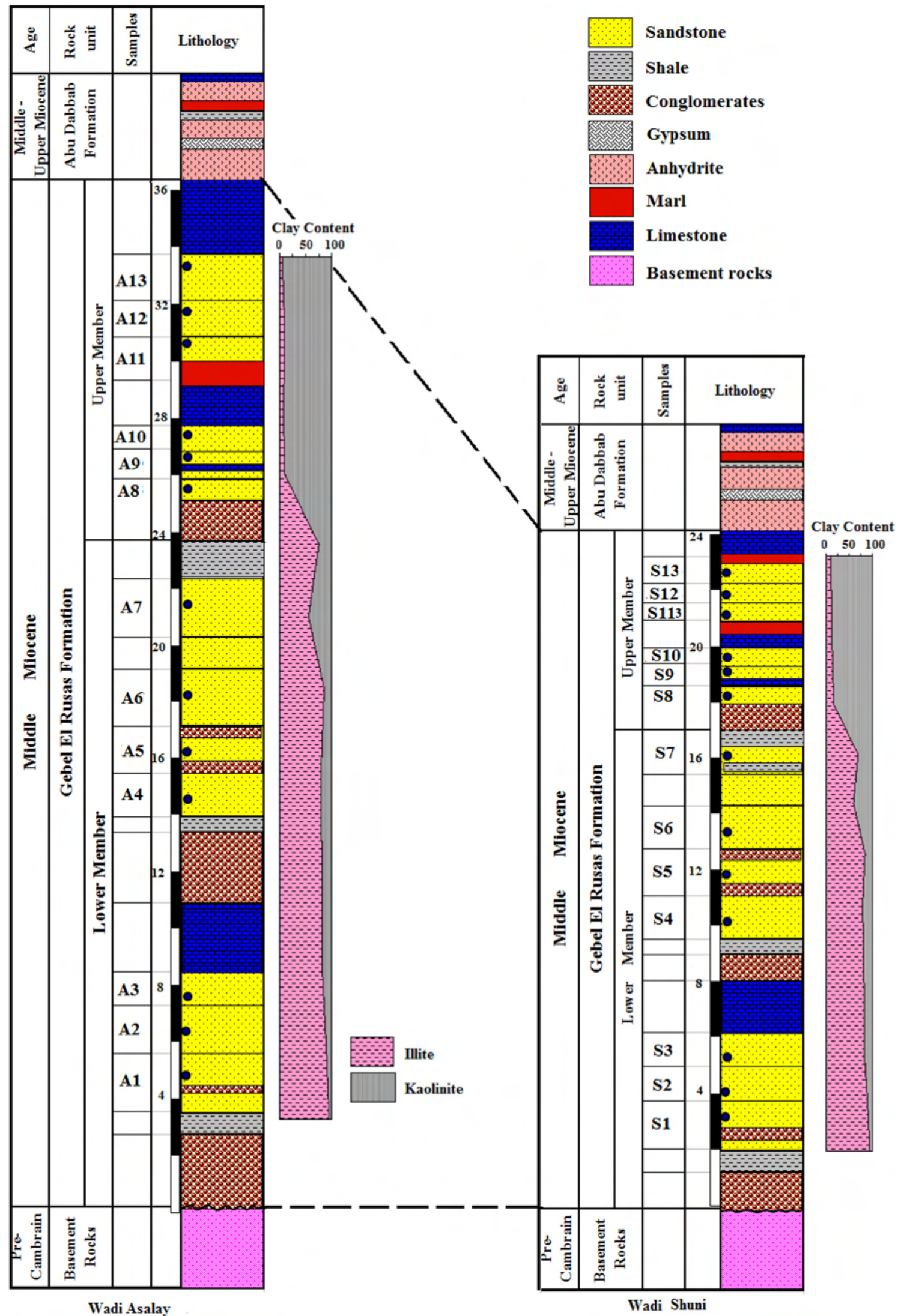

Figure 2. Lithologic logs and clay content (\%) of the Middle Miocene Gebel El Rusas sandstones at studied sections. 
due to rift subsidence and/or global sea level rise. This marine transgression is represented by the fossiliferous carbonates of Gebel EI Rusas Formation. By the Late Miocene time, a salinity crisis had occurred where a great evaporitic sedimentation took place, resulting in deposition of the $\mathrm{Abu}$ Dabbab Formation.

The lithological characteristics of the rocks of the Gebel El Rusas Formation and their areal distribution show that they began accumulation as piedmont boulders bed along the border of actively sinking faulted trough, as indicated by the presence of a granitic boulders bed at its base and by the lithological characteristics of the lower beds of the Formation (El-Akkad and Dardir 1966). These conditions gradually changed to shallow marine conditions, the upper member have been deposited in a subsiding fault trough under conditions of rapid burial and rapid erosion.

\section{Samples and methodology}

In this study, two stratigraphic sections were measured and described representing the Middle Miocene Gebel El Rusas Formation (figure 2). Twenty-six thin-sections of the Middle Miocene Gebel El Rusas sandstone samples were prepared for detailed petrographic study. Framework grains were counted for each thin section. The point counts (300 grains) were done using both GazziDickinson (Gazzi 1966; Dickinson 1970) and Ingersoll et al. (1984) methods.

The morphology and the textural relationships among minerals were examined in 8 gold-coated samples with scanning electron microscope (SEM) equipped with EDAX spectrometer (EDS) system, using an accelerating voltage of $10 \mathrm{kV}$. In order to identify the mineralogical composition of sandstones, X-ray diffraction (XRD) analyses of the $<2 \mu \mathrm{m}$ fraction were performed in a Philips PW 1729 diffractometer in eight oriented samples. The samples were air-dried, ethylene glycol-saturated and heated at $550^{\circ} \mathrm{C}$ for $2 \mathrm{hrs}$. SEM-EDS, XRF spectrometry technique and XRD analyses were performed at the laboratory of the National Research Center, Cairo, Dokki, Egypt and the laboratory of Nuclear Materials Authority, Cairo, El Katameya, Egypt. The major oxides and 14 trace elements were determined in 26 bulk samples by X-ray fluorescence (XRF) spectrometry, as per the procedure given by Ahmedali (1989). Final analysis was carried out using a Rigaku model RIX3000 equipped with a Rh tube. Calibration curves were prepared using international reference materials (Lozano and Bernal 2005). The US Geological Survey standards AGV-1, MAG-1 and SCo-1 were used for calibration, and the analytical precision for major and trace elements are generally better than $5 \%$.

The correlation coefficient was carried out for the chemical data by using the method of Davis (1986). Loss of ignition (LOI) was estimated by heating the dried sample at $1000^{\circ} \mathrm{C}$ for $2 \mathrm{hrs}$. Major-element data were recalculated to an anhydrous (LOI-free) basis and adjusted to $100 \%$ before using them in various diagrams. Total iron is reported as $\mathrm{Fe}_{2} \mathrm{O}_{3}$ (Cullers 2000).

\section{Results}

\subsection{Petrography}

The sandstones of the Lower and Upper Gebel El Rusas Formation are loosely indurated to hard. The mean grain size ranges from fine to very coarse-grained. A major portion of the framework grains is subangular to subrounded and moderate to poorly sorted (table 1). The framework grains are monocrystalline quartz (Qm), polycrystalline quartz (Qp), K-feldspar (KF), plagioclase $(\mathrm{PF})$, and lithic fragments $\left(\mathrm{L}_{\mathrm{F}}\right)$. Quartz is the most abundant framework grain in the sandstones, constituting an average $73.2 \%$ of rock volume (table 1). Sandstone classification was made using Dott-McBride scheme (figure 3a). The sandstones of the Gebel El Rusas Formation are arkoses and subarkoses. Arkoses present in the Lower Member whereas the subarkoses recorded only in the Upper Member.

The average quartz-feldspar-lithic fragment (QFR) ratio is $\mathrm{Q}_{66} \mathrm{~F}_{29} \mathrm{R}_{5}$ for the Lower Member. The matrix and cement constitutes about $17 \%$ of the rock. Matrix partly consists of clay minerals and detrital constituents. The observed type of cement includes dolomite, silica and iron oxides (figure 4). Among quartz grains, non-undulatory monocrystalline quartz is dominant over undulatory monocrystalline quartz (figure 4a). Polycrystalline quartz is a minor constituent and exhibits straight to slightly curved intercrystal boundaries (figure $4 \mathrm{~b}, \mathrm{c}$ ). Some of the non-undulatory monocrystalline quartz grains contain inclusions (figure 4c). Orthoclase feldspar is the most common 


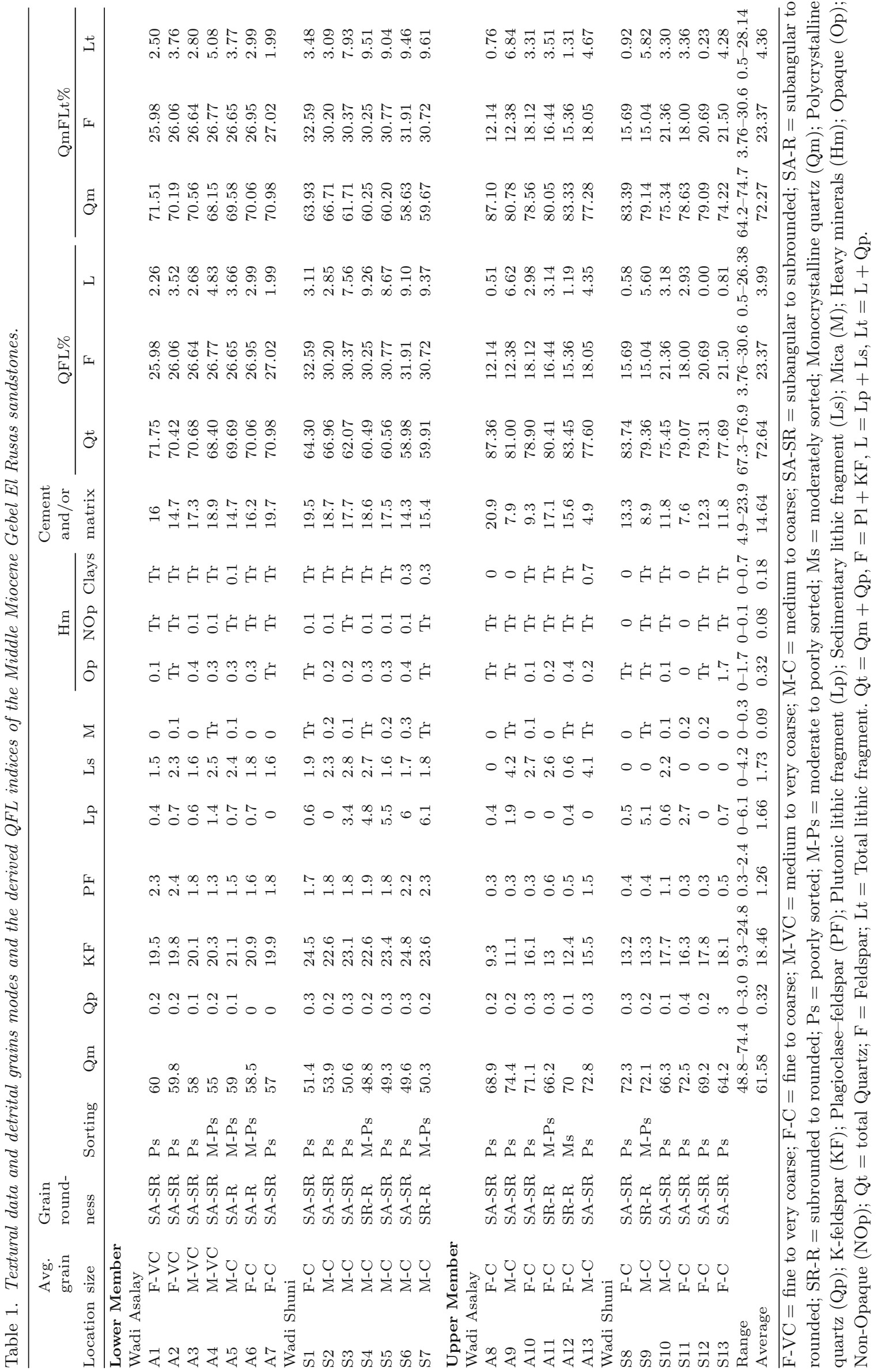




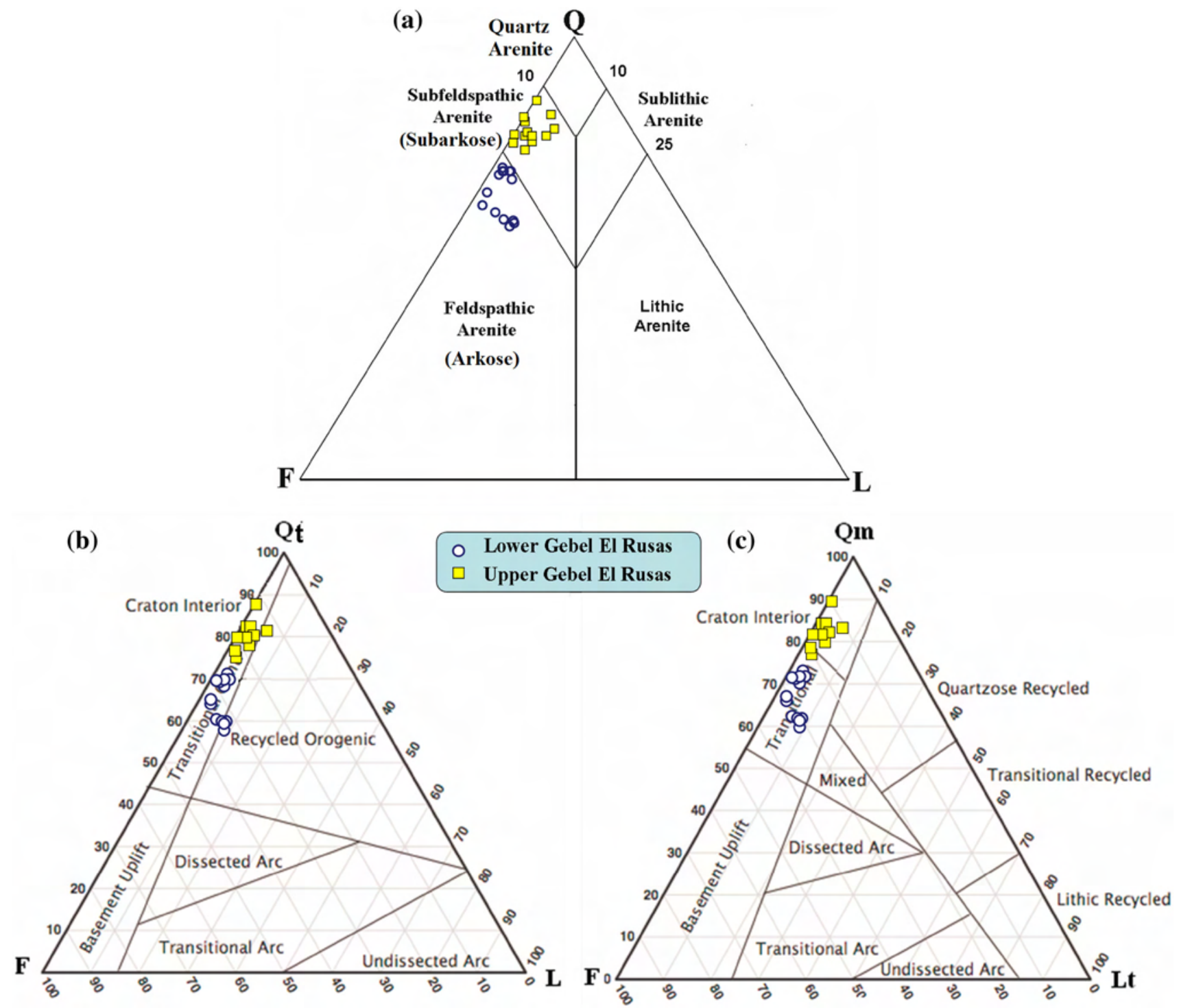

Figure 3. (a) QFL triangular diagram shows the classification of the Gebel El Rusas sandstones, modified after Dott (1964) and McBride (1963); (b) QtFL, and (c) QmFLt ternary diagrams for the Gebel El Rusas sandstones, after Dickinson et al. (1983).

type with subordinate amount of microcline (figure 4d) and perthite (figure 4e). Small amounts of plagioclase feldspar are also present (figure $4 \mathrm{a}-\mathrm{c}$ ). Minor fresh feldspar grains may locally coexist with altered ones (figure 4b, c). Clay minerals (especially kaolinite) (figure 4f) have developed with altered feldspar grains. Rock fragments are mainly of plutonic (granite) and sedimentary (carbonate shell, quartzose siltstone and chert) fragments and may range up to $5 \%$ (table 1 ). Heavy minerals (zircon, rutile and tourmaline) and mica flakes also exist (table 1).

The average quartz-feldspar-lithic fragment (QFR) ratio is $\mathrm{Q}_{80} \mathrm{~F}_{17} \mathrm{R}_{3}$ in the Upper Member. Matrix and cement constitute about $12 \%$ of the rock. Two types of cement are observed: calcite and silica (figure 5). The quartz grains are dominantly non-undulatory monocrystalline (figure 5a) and rarely polycrystalline (figure 5b). Some of the monocrystalline (non-undulatory) quartz grains contain inclusions (figure 5b). Polycrystalline quartz exhibits straight to slightly curved intercrystal boundaries (figure 5b-d). Feldspar grains are fresh (figure $5 \mathrm{~b}$ ), and altered with pore filling kaolinite booklets (figure 5c). Rock fragments are mainly of plutonic (granitic, figure 5e, f) and carbonate rock fragments. Most of the samples are free of matrix, and intergranular spaces are entirely filled up by calcite cement. Some quartz and altered feldspar grains are smeared 

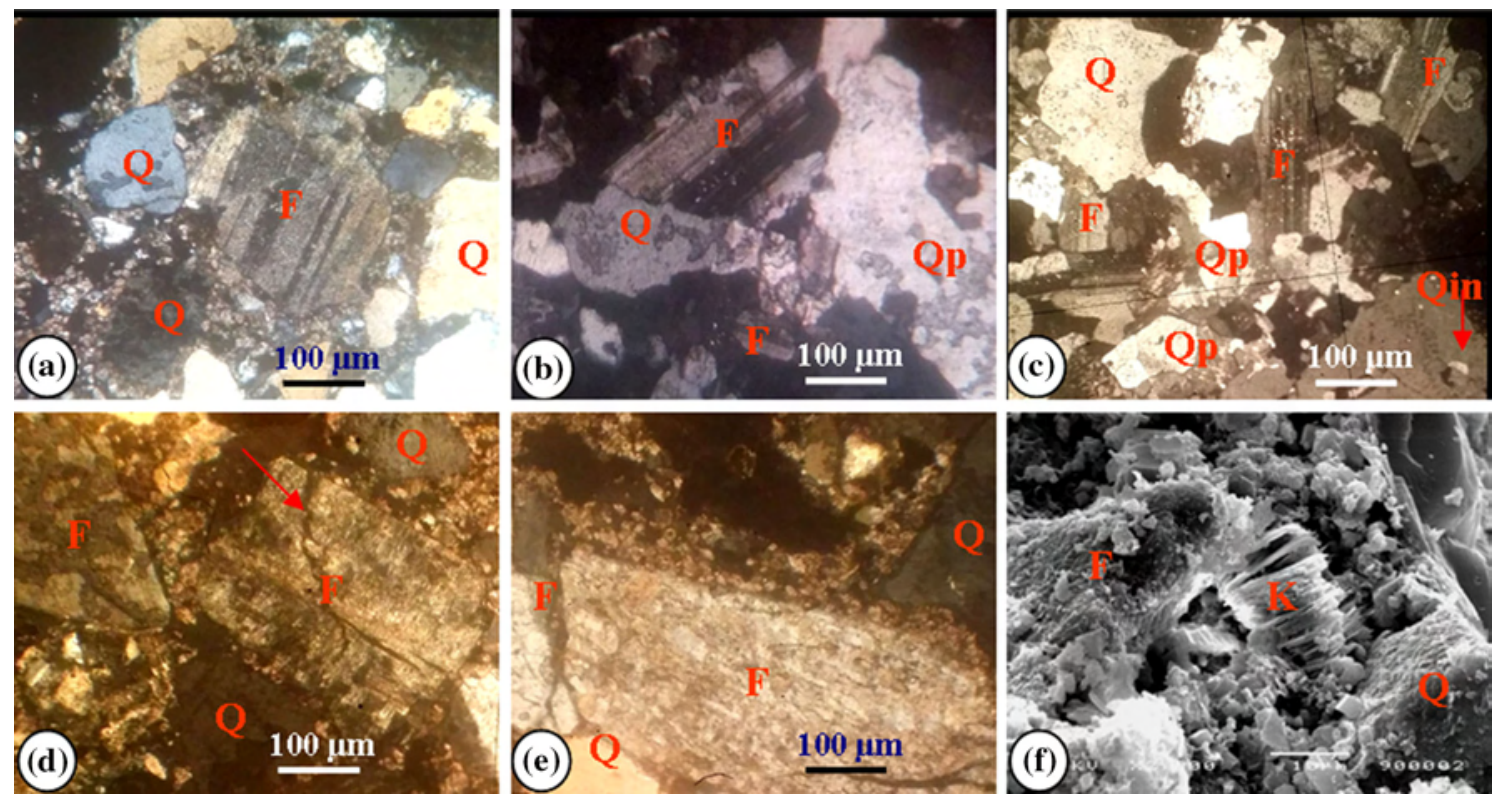

Figure 4. Photomicrograph and SEM of arkoses of the Lower Gebel El Rusas Formation: (a) Quartz (Q) and feldspar (F) grains are fine- to very-coarse grained, subangular to subrounded and poorly sorted (Note: quartz is mainly monocrystalline with undulatory extinction); (b) Fresh and altered feldspars with abundant iron oxide cement; (c) Monocrystalline and polycrystalline quartz (Qp) grain compacted with fresh and weathered feldspars (Note: quartz inclusions (Qin)); (d) Fractured and weathered feldspars (microcline and plagioclase) grains embedded in dolomite and iron oxide cements; (e) Quartz (Q) and feldspars (perthite) grains are angular, poorly sorted and poorly cemented. (f) Quartz (Q) and highly altered feldspars grains (Note: pore filling kaolinite $(\mathrm{K})$ ).

with iron oxide and some others are corroded and partially replaced by calcite cement in part (figure $5 \mathrm{~d}-\mathrm{f}$ ). Heavy minerals such as hematite, rutile, tourmaline, zircon, and muscovite also exist (table 1).

\subsection{Clay mineralogy}

The clay minerals identified in both Lower and Upper Gebel El Rusas sandstones are illite and kaolinite. The proportions of illite to kaolinite vary antipathetically (figure 2) from an illite dominated Lower Member to a kaolinite dominated Upper Member. These variations may be related to relative changes in the climatic conditions in the source area. The moderate crystallinity exhibited by the clay minerals indicates their detrital origin from weathering horizons and soils developed on silicic rocks, and transportation in a fluvial environment (Keller 1956; Abu-Zeid et al. 1989, 1991). Source area weathering is confirmed by the absence of smectite and chlorite. The absence of smectite and chlorite and predominance of kaolinite, especially at the Upper Member indicate a granitic source rock (Lonnie 1982; Tsuzuki and Kawabe 1983; Amer et al. 1989; Abu-Zeid et al. 1991).

\subsection{Major element geochemistry}

The major element data of the Lower and Upper members of the Gebel El Rusas sandstones of Wadi Asalay and Wadi Shuni are listed in table 2. The $\mathrm{SiO}_{2 \text { adj }}$ content is comparatively higher in subarkoses of the Upper Member (78.32 \pm 0.45 , $n=12$ ), than in arkoses of the Lower Member $(66.44 \pm 1.357, n=14)$, which indicate the quartz rich nature of the Upper Member. The $\mathrm{Al}_{2} \mathrm{O}_{3}$ content is high in arkoses $(11.2 \pm 0.43, n=14)$, but low in subarkoses $(5.84 \pm 0.35, n=12)$. The high $\mathrm{CaO}$ content (arkose $11.66 \pm 1.43, n=14$; subarkoses $10.3 \pm 0.51, n=12)$ is because of the presence of secondary $\mathrm{CaCO}_{3}$. The lower arkoses is slightly higher in $\mathrm{Na}_{2} \mathrm{O}$ content $(0.48 \pm 0.02, n=14)$ than in upper subarkoses $(0.2 \pm 0.01, n=12)$. The $\mathrm{Na}_{2} \mathrm{O}$ content $(<0.5 \%)$ may indicate a smaller amount of plagioclase content in the two members.

The high $\mathrm{K}_{2} \mathrm{O} / \mathrm{Na}_{2} \mathrm{O}$ ratios $(3.9 \pm 0.12, n=14$ and $5.33 \pm 0.4, n=12$ ) are attributed to the relatively common presence of K-bearing minerals such as K-feldspar and some micas (McLennan et al. 1983; Osae et al. 2006).

The $\mathrm{Al}_{2} \mathrm{O}_{3} / \mathrm{TiO}_{2}$ ratio is larger for Lower Member arkoses $(38.5 \pm 3.07, n=14)$ than for Upper Member subarkoses $(14.77 \pm 0.31, n=12)$. 


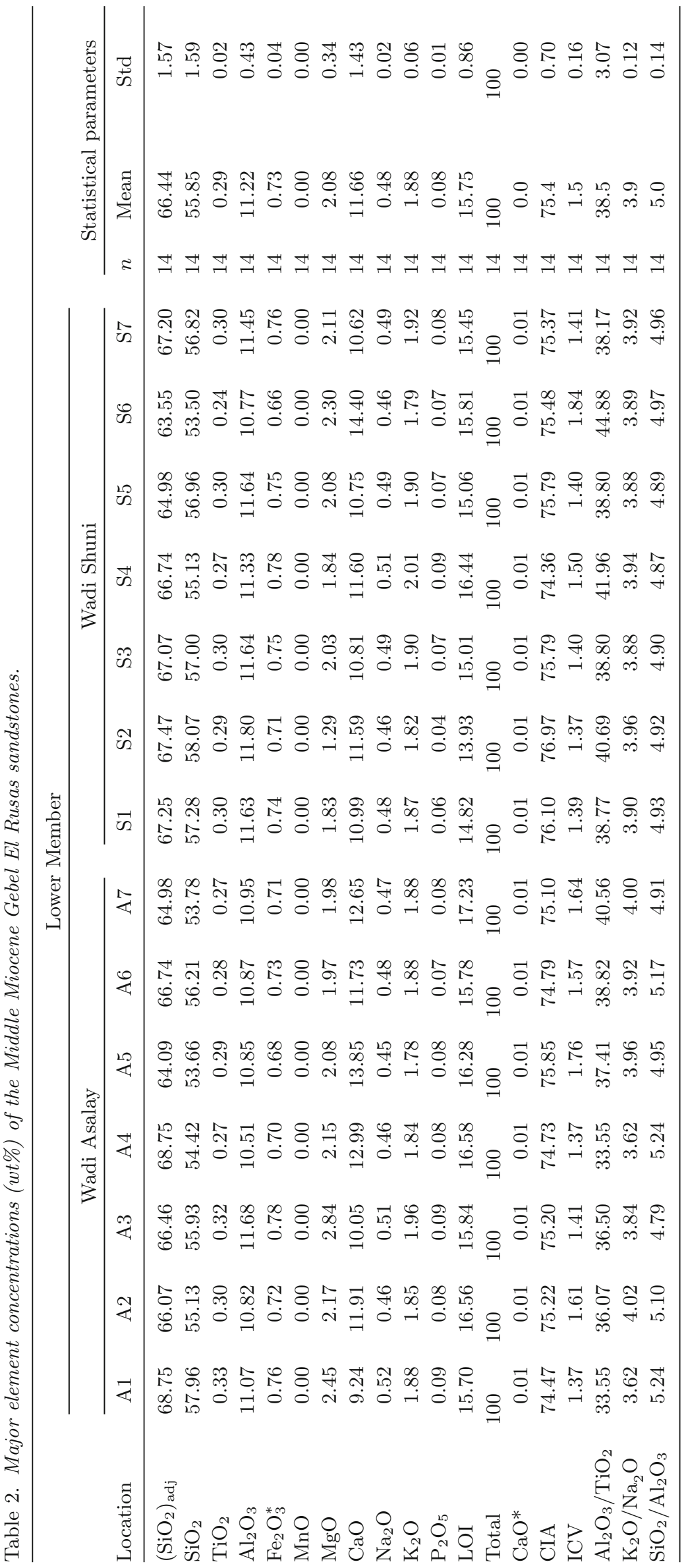




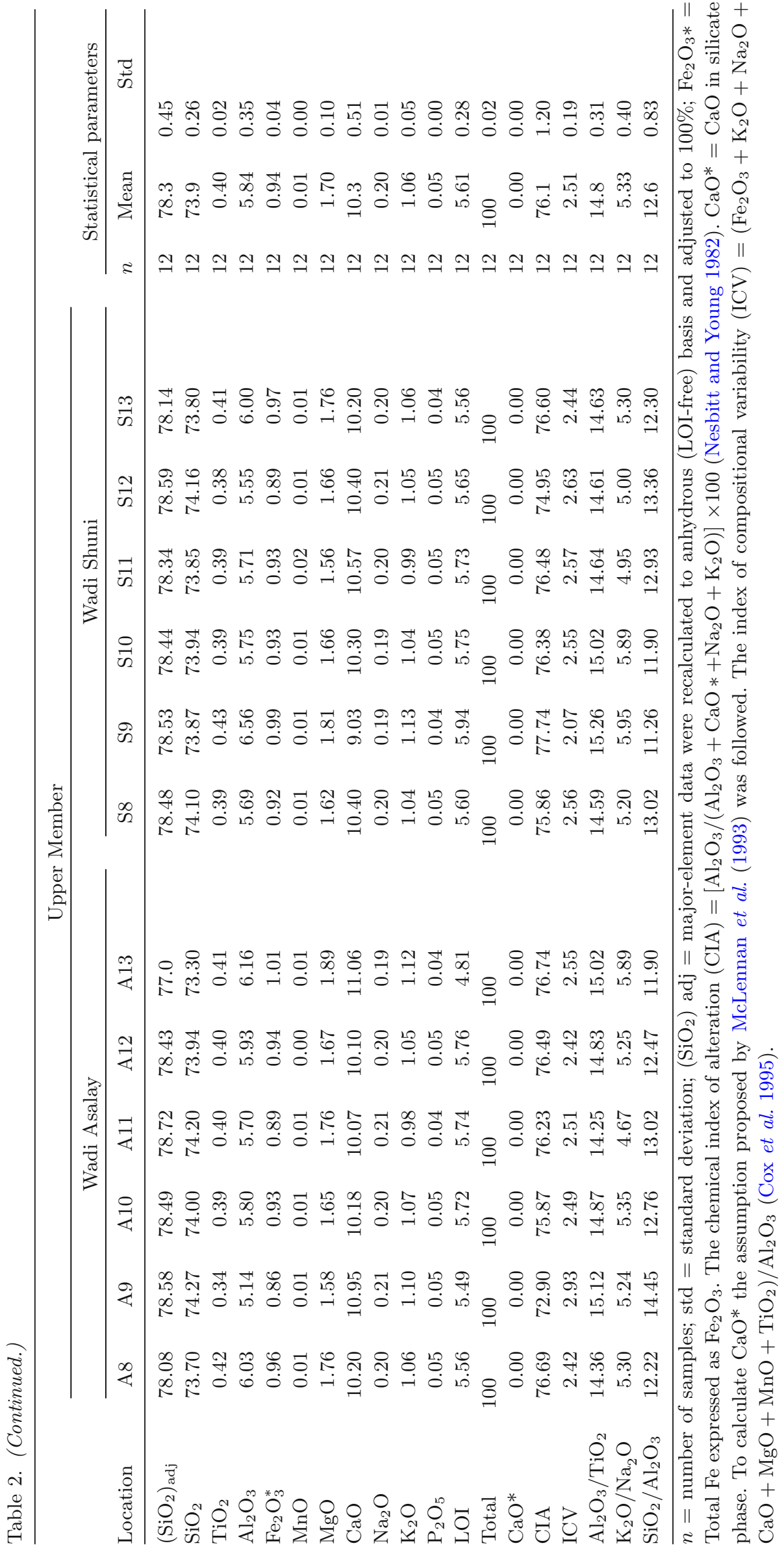



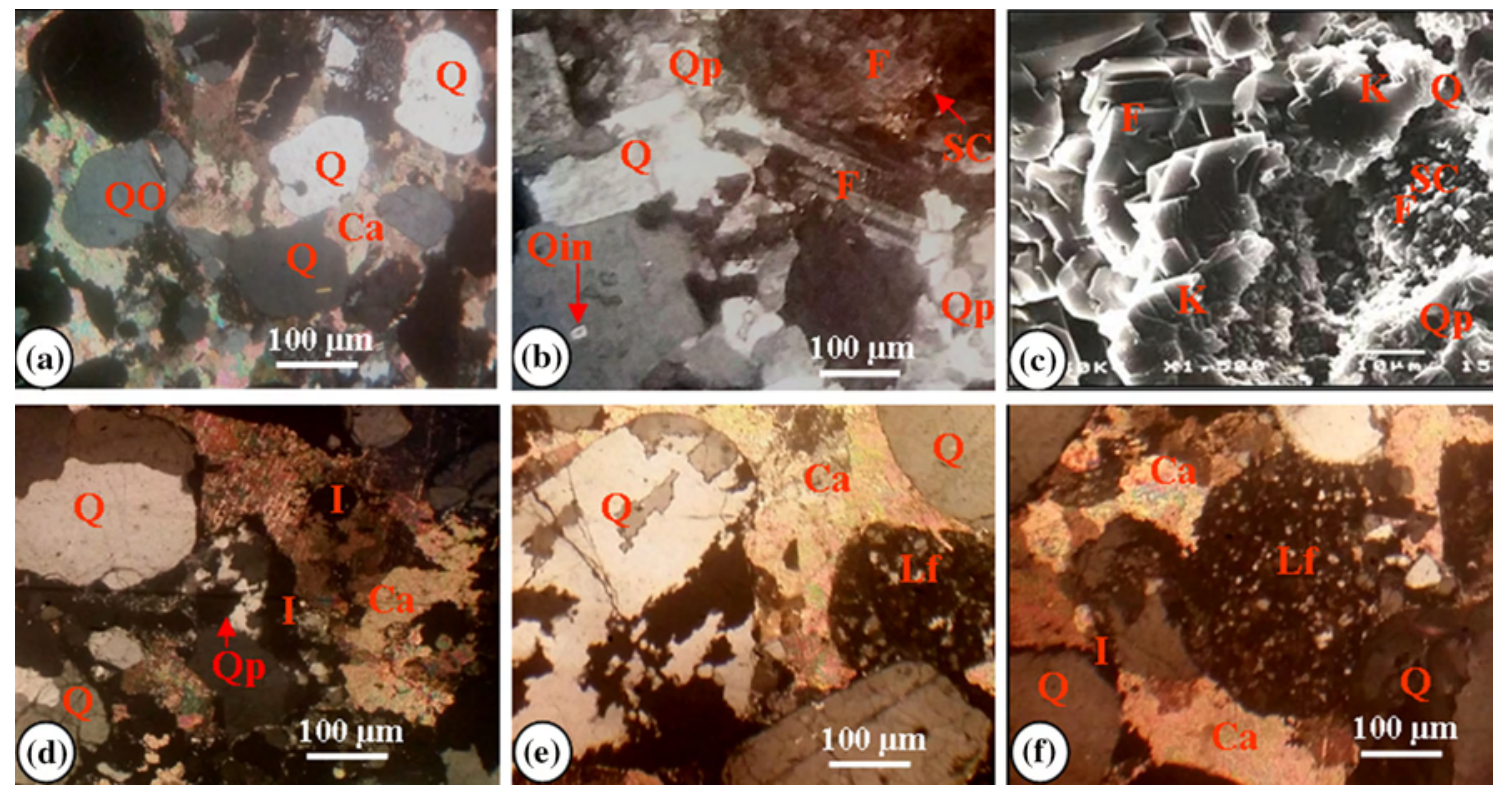

Figure 5. Photomicrograph and SEM of subarkoses of the Upper Gebel El Rusas Formation: (a) Quartz (Q) grains are medium - to very coarse grained, subangular to subrounded and poor to moderately sorted (Note: quartz is mainly monocrystalline with undulatory extinction); (b) Monocrystalline and polycrystalline quartz (Qp) grain compacted with fresh and altered feldspars (Note: feldspar altered to sericite (Sc) and quartz inclusions (Qin)); (c) Fresh and highly weathered feldspars (F) with pore filling kaolinite booklets; (d) Quartz grains embedded in calcite (Ca) and iron oxide (I) cements; (e) Quartz (Q) and lithic (plutonic) fragment (Lf) grains are well cemented and highly corroded by sparry calcite cement; (f) well round, coarse-grained monocrystalline quartz $(\mathrm{Q})$ and plutonic rock fragment (Lf) with thin rim of iron oxide (I) and abundant interstitial calcite cement $(\mathrm{Ca})$

The statistically significant positive correlation between $\mathrm{Fe}_{2} \mathrm{O}_{3}$ and $\mathrm{TiO}_{2}$, for both Lower and Upper Members sandstones $(r=0.964, n=26)$, reveals the abundance of $\mathrm{Fe}$ and Ti-rich minerals (hematite and rutile).

\subsection{Trace element geochemistry}

The trace element data and elemental ratios of the Middle Miocene Gebel El Rusas sandstones are reported in table 3. The Lower Member arkoses are higher in $\mathrm{Sr}, \mathrm{V}, \mathrm{Ni}, \mathrm{Co}, \mathrm{Cr}, \mathrm{Zn}, \mathrm{Cu}, \mathrm{Zr}, \mathrm{U}, \mathrm{Th}, \mathrm{Pb}$ and $\mathrm{Rb}$ than the Upper Member subarkoses. Both the Lower and the Upper Member sandstones are depleted in Co and U compared to average upper continental crust (UCC, figure 6). The sandstones and UCC have similar $\mathrm{V}, \mathrm{Ni}, \mathrm{Cr}, \mathrm{Th}, \mathrm{Pb}$, and $\mathrm{Sc}$ concentrations. However, the $\mathrm{Sr}, \mathrm{Ba}, \mathrm{Zr}$ and $\mathrm{Rb}$ content in both arkoses and subarkoses is higher than the UCC.

The correlation between $\mathrm{SiO}_{2}$ and trace elements is statistically not significant for both Lower and Upper members. However, the correlation between $\mathrm{Al}_{2} \mathrm{O}_{3}$ and some trace elements is statistically significant for both lower and upper members (e.g.,
Sr, $r=0.718 ; \mathrm{Zn}, r=0.704 ; \mathrm{Cu}, r=0.759)$ signifying that these elements are associated with clay minerals rather than in source rocks (Armstrong-Altrin et al. 2015a).

\section{Discussion}

\subsection{Provenance}

The textural features such as fine-medium to coarse grains, moderate to poorly sorting and the subangular to subrounded shape and high-percentage of unstable grain: feldspar (9.6-27.2\%) and other rock fragments $(0.0-10.3 \%)$; (table 1), indicate that the Gebel El Rusas sandstones show short transport distance and quick burial. The Gebel El Rusas sandstones deposited in the craton interior to transitional continental (figure 3b, c), derived from the exposed basement shield area, probably from platform or uplifted basement rocks. They might be derived mainly from weathered and low-lying crystalline basement rocks. The presence of mixed altered and fresh feldspars may reflect immature sediments interfingered with submature phases. This would favour a weathered 


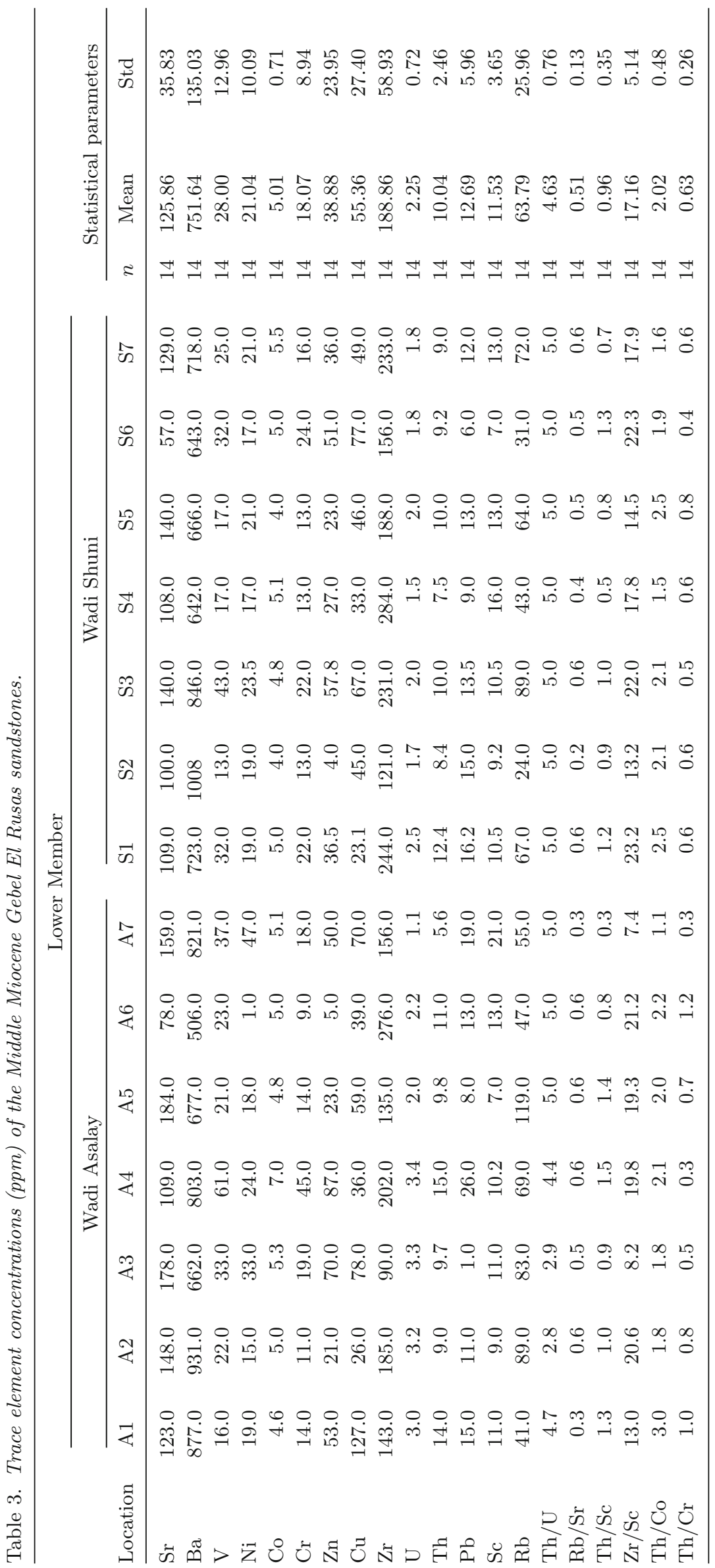




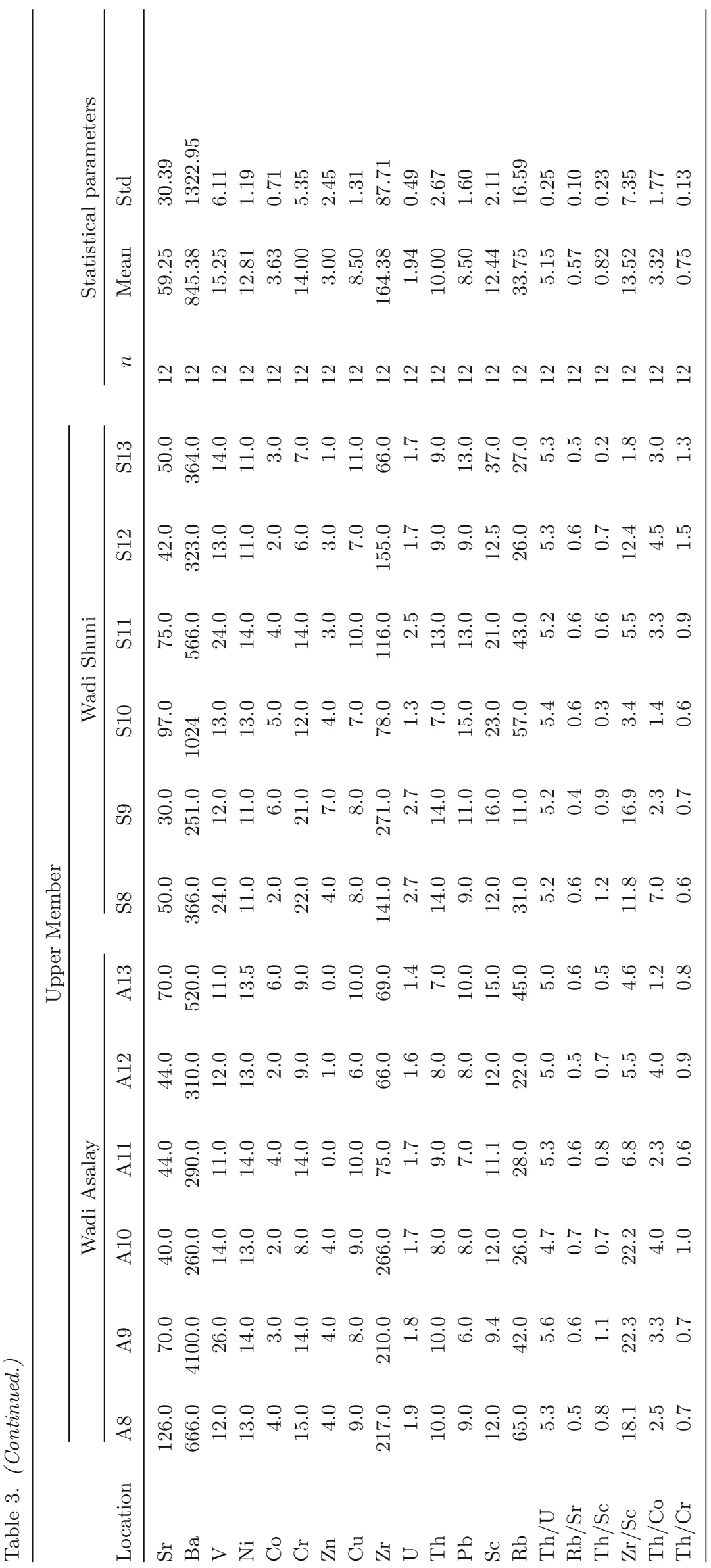



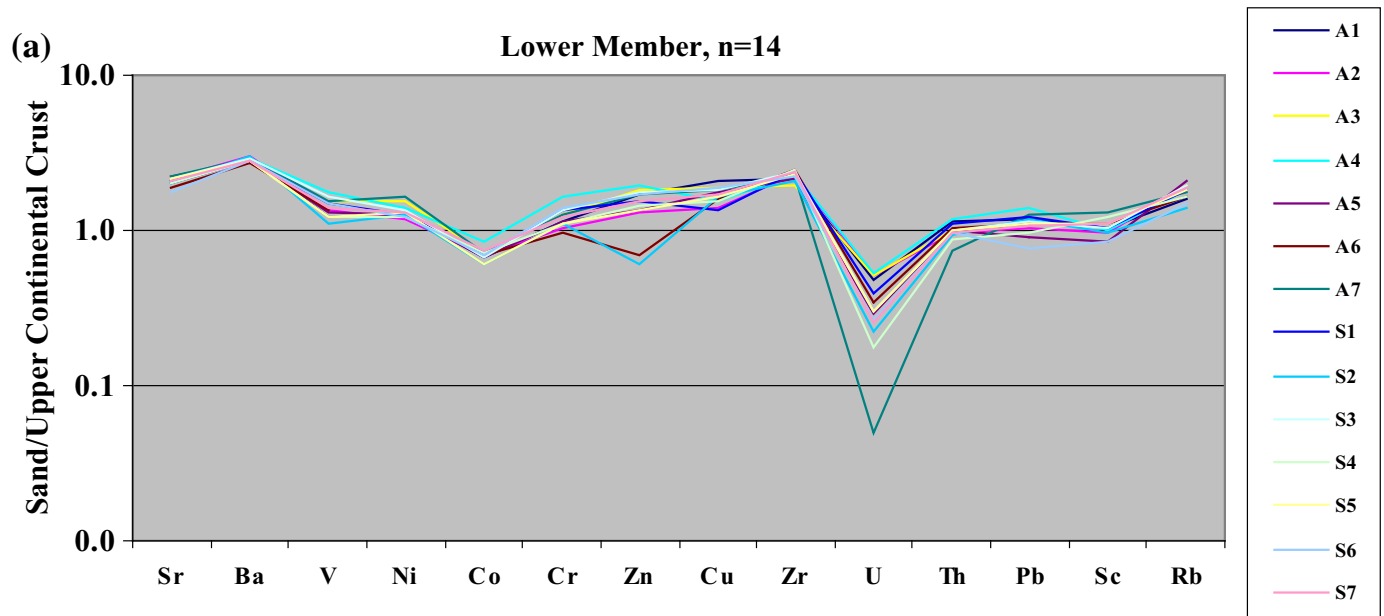

(b)

Upper Member, $\mathbf{n}=12$

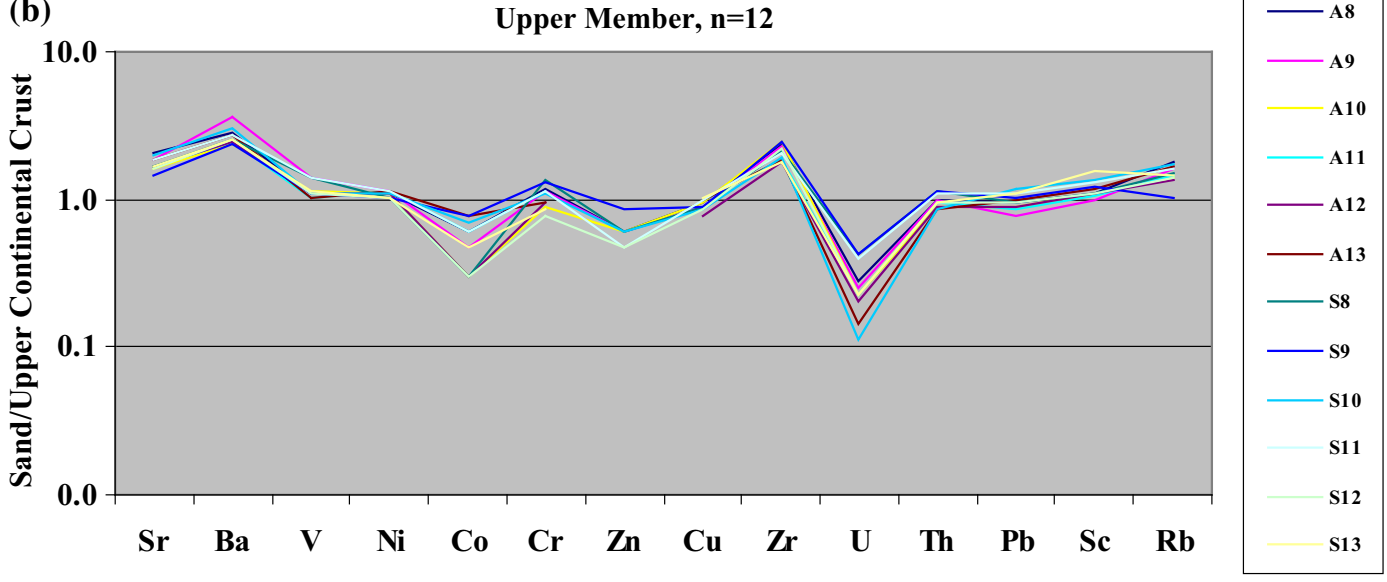

Figure 6. Multi-element normalised diagram for the Middle Miocene Gebel El Rusas sandstone samples, normalised against average upper continental crust (Taylor and McLennan 1985). A horizontal line for sand/upper continental crust value of 1 is included for reference. (a) Lower Member arkoses and (b) Upper Member subarkoses.

crystalline granitic source terrain (Akarish and ElGohary 2008). The presence of plutonic (granite) and sedimentary (carbonate shell, quartzose siltstone and chert) rock fragments, suggesting that the Gebel El Rusas sandstones were derived mainly from relatively low lying granitoid and supplemented by recycled sands from associated platform or passive margin basins (Akarish and El-Gohary 2008).

The dominance of unstrained monocrystalline quartz grains that contain common inclusions are present in most samples, suggesting a plutonic origin (Basu et al. 1975). The polycrystalline quartz grains are composed of $2-5$ subcrystals with straight to slightly curved intercrystalline boundaries, suggesting a plutonic source (Blatt et al. 1980). The predominance of K-feldspar over plagioclase together with muscovite suggests a plutonic source (Osae et al. 2006). The abundance of kaolinite and illite and absence of smectite and chlorite clay mineral indicate a granitic source rock (Abu-Zeid et al. 1991).

In addition, major element concentrations and its elemental ratios were also used widely to interpret the nature of provenance (Armstrong-Altrin et al. $2015 \mathrm{a}, \mathrm{b})$. The $\mathrm{Al}_{2} \mathrm{O}_{3} / \mathrm{TiO}_{2}$ ratio can be used as a good indicator to identify the source rock. This ratio increases from 3-8 (in mafic) to 8-21 (in intermediate) and 21-70 (in felsic) igneous rocks (Nagarajan et al. 2015). The $\mathrm{Al}_{2} \mathrm{O}_{3} / \mathrm{TiO}_{2}$ ratio is $(38.5 \pm 3.07)$ for Lower Member and $(14.77 \pm 0.31)$ for the Upper Member subarkoses, indicating an intermediate to felsic source rock. Also, the high values of $\mathrm{K}_{2} \mathrm{O} / \mathrm{Na}_{2} \mathrm{O}$ ratio (table 2 ) may indicate a K-rich granitic source rocks rather than basic rocks (Potter 1978).

The relative contribution of mafic materials by the source rocks to the study areas can be identified by the enrichment or depletion of ferromagnesian trace elements like $\mathrm{Cr}, \mathrm{Ni}, \mathrm{Sc}$, and $\mathrm{V}$ in sediments 
Table 4. Range of elemental ratios of the Lower and Upper Gebel El Rusas sandstones in this study compared to the ratios in similar fractions derived from felsic, mafic rocks, and upper continental crust.

\begin{tabular}{lccccc}
\hline $\begin{array}{l}\text { Elemental } \\
\text { ratio }\end{array}$ & $\begin{array}{c}\text { Lower } \\
\text { sandstones }\end{array}$ & $\begin{array}{c}\text { Upper } \\
\text { sandstones }\end{array}$ & $\begin{array}{c}\text { Range of sediment } \\
\text { from felsic sources } \\
\text { (Cullers 2000) }\end{array}$ & $\begin{array}{c}\text { Range of sediment from mafic } \\
\text { sources (Cullers 1994, 2000; } \\
\text { Cullers and Podkovyrov 2000) }\end{array}$ & $\begin{array}{c}\text { UCC } \\
\text { (Taylor and McLennan 1985) }\end{array}$ \\
\hline Th/Sc & $0.3-1.5$ & $0.2-1.2$ & $0.84-20.5$ & $0.05-0.22$ & 0.79 \\
Th/Co & $1.1-3.0$ & $1.2-7.0$ & $0.67-19.4$ & $0.04-1.40$ & 0.63 \\
Th/Cr & $0.3-1.2$ & $0.6-1.5$ & $0.13-2.70$ & $0.02-0.05$ & 0.13 \\
\hline
\end{tabular}

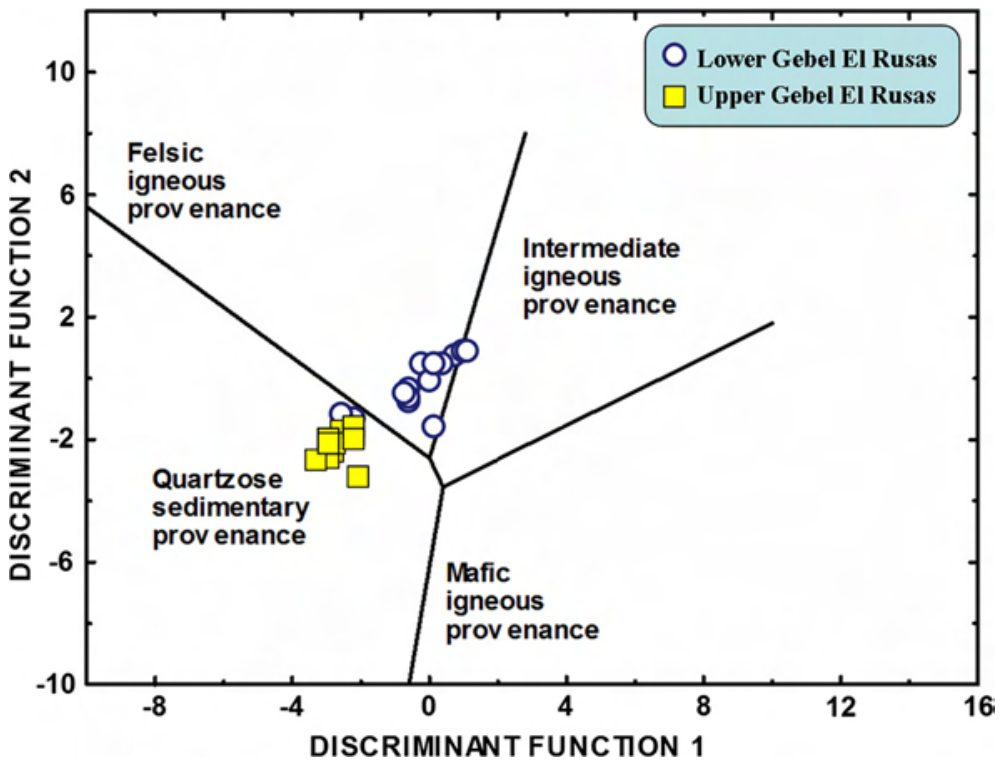

Figure 7. Discriminant function diagram using major elements for the Upper and Lower Gebel El Rusas sandstones (Provenance fields are after Roser and Korsch 1988).

(Armstrong-Altrin et al. 2004). Anomalously, high values of $\mathrm{Cr}(>150 \mathrm{ppm})$ and $\mathrm{Ni}(>100 \mathrm{ppm})$ are indicative of ultramafic sources (Garver et al. 1996). The Lower and Upper Gebel El Rusas sandstones are largely depleted on $\mathrm{Cr}(15.54 \pm 7.81, n=$ $26)$ and $\mathrm{Ni}(17.15 \pm 8.48, n=26)$ contents, indicating limited contribution of intermediate rocks in the source area (Armstrong-Altrin et al. 2013). The ratios such as $\mathrm{Th} / \mathrm{Sc}, \mathrm{Th} / \mathrm{Co}$, and $\mathrm{Th} / \mathrm{Cr}$ are sensitive to the nature of provenance and are highly useful to differentiate mafic from felsic source rocks (Cullers 2000). These ratios of Lower and Upper Gebel El Rusas sandstone were compared with sediments derived from the mafic and felsic source rocks (table 4). This comparison reveals that the lower and upper Gebel El Rusas sandstones in both the studied sections received a major contribution from felsic rocks.

In sedimentary provenance studies, the discriminant function diagram proposed by Roser and Korsch (1988) is frequently used (Vdačný et al.
2013; Armstrong-Altrin et al. 2015b). This diagram helps to discriminate four major provenance categories, i.e., mafic (P1), intermediate (P2), felsic (P3) and quartzose recycled (P4). On this discriminate function diagram (figure 7 ) the Lower Gebel El Rusas arkoses plot in the felsic igneous provenance and the Upper Gebel El Rusas subarkoses in the quartzose sedimentary provenance fields, suggesting their derivation from a cratonic interior or recycled origin (figure 7 ).

The $\mathrm{K}_{2} \mathrm{O} / \mathrm{Al}_{2} \mathrm{O}_{3}$ vs. $\mathrm{Rb} / \mathrm{Al}_{2} \mathrm{O}_{3}$ bivariate plot has been widely used as indicators for source composition (Armstrong-Altrin et al. 2012), since the $\mathrm{K}_{2} \mathrm{O}$ and $\mathrm{Rb}$ contents in sediments are sensitive during source composition and processes (ArmstrongAltrin et al. 2015b). This plot (figure 8) is nearly uniform for both Lower and Upper Gebel El Rusas sandstones, which indicate the same source composition (felsic).

The coexistence of lower arkosic and upper subarkosic sandstones in studied sections indicate 


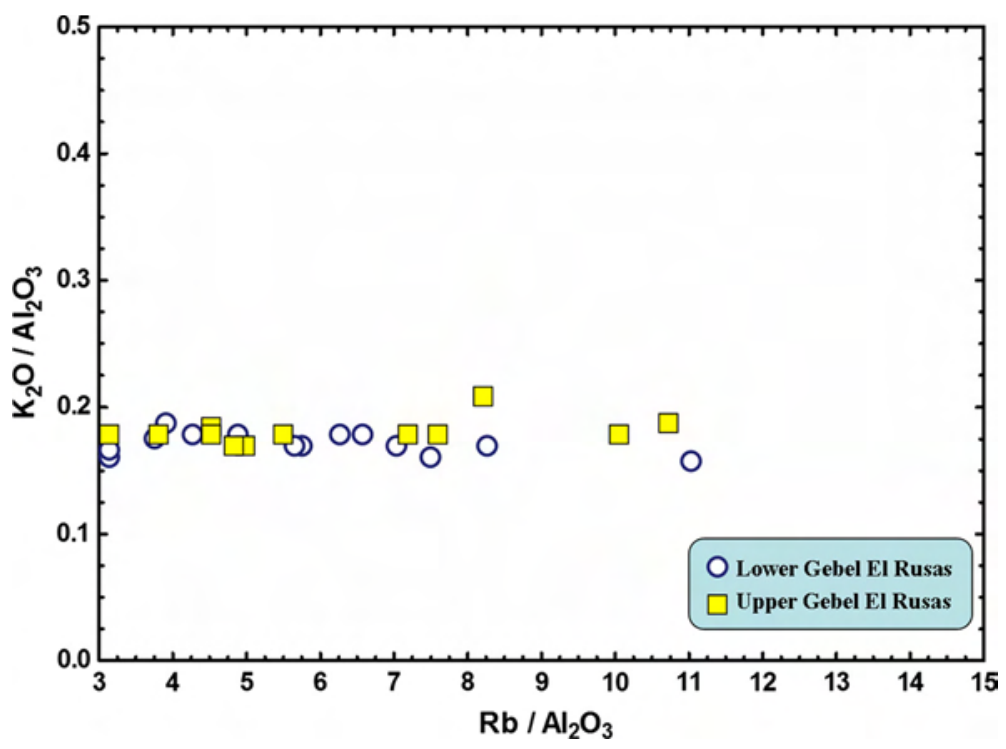

Figure 8. $\mathrm{K}_{2} \mathrm{O} / \mathrm{Al}_{2} \mathrm{O}_{3}$ vs. $\mathrm{Rb} / \mathrm{Al}_{2} \mathrm{O}_{3}$ bivariate diagram for the Lower and Upper Gebel El Rusas sandstones.

rapid uplift of the source area and quick subsidence of the basin, followed by a period of quiescence within an overall transgressive-regressive cycle in a rift tectonic regime (Zaid 2015a). Finally, the petrographical and geochemical data suggests that the sandstones of the Gebel El Rusas were derived from Proterozoic granite, which have been uplifted and exposed by the Rifting Orogeny, initiated during Oligocene and continued till post Miocene.

\subsection{Source area weathering and sediment recycling}

The chemical composition of clastic sediments can provide useful information about weathering condition in the source area (Liu et al. 2015). The chemical index of alteration (CIA) proposed by Nesbitt and Young (1982) is the most widely used chemical index to assess the degree of chemical weathering in the source area. This index was calculated using the molecular proportions as shown in the equation below

$$
\mathrm{CIA}=\frac{\left[\mathrm{Al}_{2} \mathrm{O}_{3}\right]}{\left(\mathrm{Al}_{2} \mathrm{O}_{3}+\mathrm{CaO} *+\mathrm{Na}_{2} \mathrm{O}+\mathrm{K}_{2} \mathrm{O}\right)} \times 100
$$

where $\mathrm{CaO}^{*}$ is the amount of $\mathrm{CaO}$ incorporated in the silicate fraction of the rock. $\mathrm{CaO}$ values were accepted only if $\mathrm{CaO}<\mathrm{Na}_{2} \mathrm{O}$; consequently, when $\mathrm{CaO}>\mathrm{Na}_{2} \mathrm{O}$, it was assumed that the concentration of $\mathrm{CaO}$ equals to that of $\mathrm{Na}_{2} \mathrm{O}$ (McLennan et al. 1993). CIA values of the Lower and Upper Gebel El Rusas sandstones are $75.4 \%$ and $76.08 \%$ respectively, suggesting that the source rocks of these sandstones could be uplifted basement rocks. The differences in CIA between the two members are not statistically significant, indicating a similar degree of weathering.

The ternary plot $\mathrm{Al}_{2} \mathrm{O}_{3}-\mathrm{CaO} *+\mathrm{Na}_{2} \mathrm{O}-\mathrm{K}_{2} \mathrm{O}$ (figure 9) is a graphic representation, in order to evaluate the extents of chemical weathering, where unweathered rocks plot along the left side of the plagioclase-K-feldspar line (Nesbitt and Young 1984). In this plot, the data clusters are found near the A-K edge, along illite composition, indicating a moderate degree of weathering of the source rocks. Samples of the Lower and Upper Members cluster at one point, parallel to the A-CN line (figure 9) indicating their similar extents of chemical weathering. The extrapolation of the line from the weathered sample points indicate the provenance of the Gebel El Rusas sandstones to be from average granite (Nesbitt and Young 1984).

'Sedimentary recycling' can be identified using $\mathrm{Rb} / \mathrm{Sr}$ ratios, where $\mathrm{Sr}$ easily leaches compared to $\mathrm{Rb}$ and this leads to a significant increase in the $\mathrm{Rb} / \mathrm{Sr}$ ratio, and high ratios have been interpreted to be indicators of strong weathering and sediment recycling (McLennan et al. 1993). The $\mathrm{Rb} / \mathrm{Sr}$ ratios of the Lower and Upper Members $(0.51 \pm 0.13, n=14$, and $0.57 \pm 0.1, n=12$, respectively) are slightly lower than the average PAAS value (0.80; Taylor and McLennan 1985), suggest moderate weathering intensity in the source region.

The index of compositional variability (ICV; Cox et al. 1995) is considered as an important parameter to evaluate the maturity of sediments (Cullers 


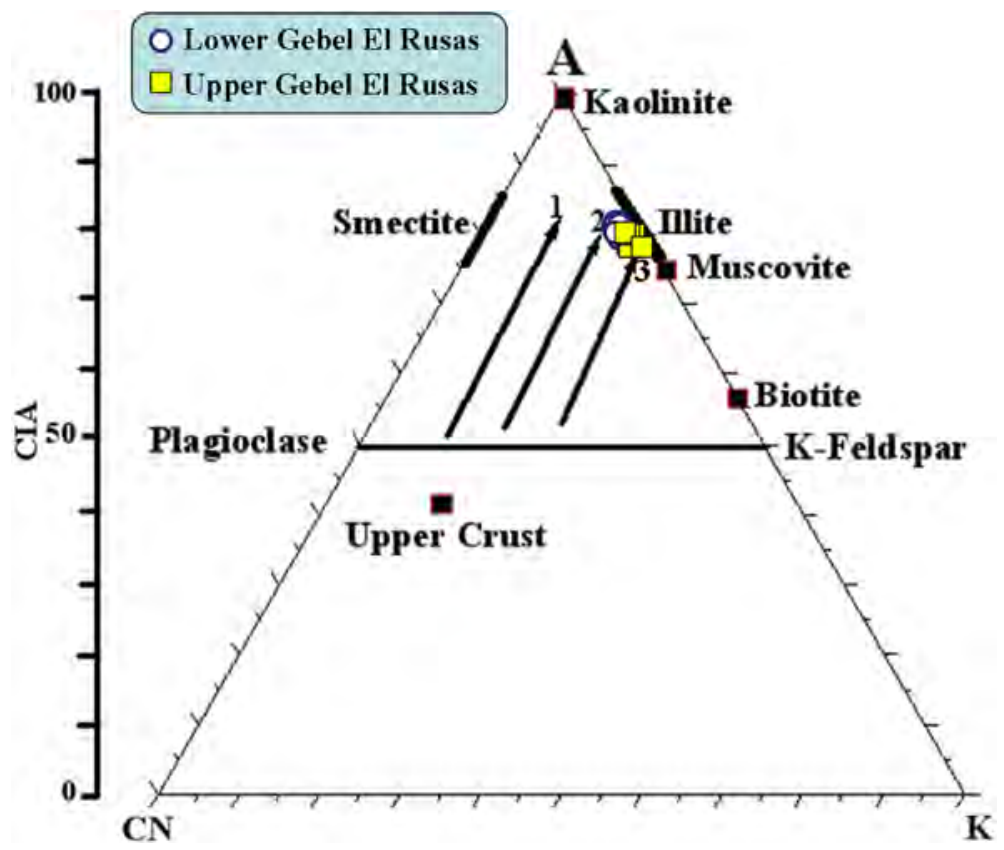

Figure 9. A-CN-K ternary diagram of molecular proportions of $\mathrm{Al}_{2} \mathrm{O}_{3}-\left(\mathrm{CaO}+\mathrm{Na}_{2} \mathrm{O}\right)-\mathrm{K}_{2} \mathrm{O}$ for the Lower and Upper Gebel El Rusas sandstones (after Nesbitt and Young 1984). Also plotted is the average upper continental crust (Taylor and McLennan 1985), as well as some rock forming minerals important in silicate rock weathering; shown at the side is the CIA scale. Arrows 1-3 represent the weathering trends of granodiorite, adamellite and granite, respectively (Nesbitt and Young 1984).

2000). ICV values are high $(>1)$ for detrital ferromagnesian minerals and feldspars and low $(<1)$ for the clay minerals subjected to intensive weathering processes (Cox et al. 1995; Cullers 2000). The average ICV values of lower Gebel El Rusas arkoses $(1.5 \pm 0.16, n=14)$ and upper Gebel El Rusas subarkoses $(2.51 \pm 0.19, n=12)$ are $>1$ (table 2), indicating the abundance of less weathered detrital minerals and were probably derived from the source area with high relief. Compositionally immature sediments with high ICV values are first-cycle deposits derived by low to moderate weathering of source rocks (Armstrong-Altrin et al. 2015b).

The $\mathrm{SiO}_{2} / \mathrm{Al}_{2} \mathrm{O}_{3}$ ratio is a widely used measure to understand the maturity of sediments, where a high value represents compositionally matured sediments (e.g., Etemad-Saeed et al. 2011; Madhavaraju 2015). The average $\mathrm{SiO}_{2} / \mathrm{Al}_{2} \mathrm{O}_{3}$ ratio in basic igneous rocks is 3 , whereas it is about 5 in acid igneous rocks, hence the values $>5$ in clastic sediments indicate sediment maturity (Roser et al. 1996; Armstrong-Altrin et al. 2015b). The $\mathrm{SiO}_{2} / \mathrm{Al}_{2} \mathrm{O}_{3}$ ratio values $(5.0 \pm 0.14, n=14$ and $12.63 \pm 0.83, n=12)$ in the Lower and Upper Gebel El Rusas sandstones, respectively (table 2), which is slightly higher than the average $\mathrm{UCC}$ value $(\sim 4)$, indicating low to moderate mineralogical maturity.
The variation in the $\mathrm{SiO}_{2} / \mathrm{Al}_{2} \mathrm{O}_{3}$ ratio between the two members also reveals the difference in $\mathrm{SiO}_{2}$ content. The Upper Member subarkoses are enriched in $\mathrm{SiO}_{2}$ content with elevated $\mathrm{SiO}_{2} / \mathrm{Al}_{2} \mathrm{O}_{3}$ ratio. This indicates that the Upper Member subarkoses is slightly recycled compared to Lower Member arkoses.

Similarly, the $\mathrm{Th} / \mathrm{Sc}$ vs. $\mathrm{Zr} / \mathrm{Sc}$ plot of Sharma et al. (2013) show that the samples of the lower arkoses and the upper subarkoses follow the trend 1 (figure 10), suggesting first-cycle deposits, low to moderate weathering and low maturity.

\subsection{Tectonic setting}

The modal data of the Lower Gebel El Rusas sandstones mostly plot in the transitional continental fields, whereas the Upper Gebel El Rusas sandstones fall mainly in the craton interior fields (figure 3b, c; Dickinson et al. 1983). These sandstones are immature (Lower Member) to submature (Upper Member). The high percentage of unstable grain (feldspars and rock fragments) in both lower (av. 34\%) and upper (av. 20\%) members, indicate that these sandstones show short transport distance, quick burial and are typically rift sandstone (Zaid 2015a). 


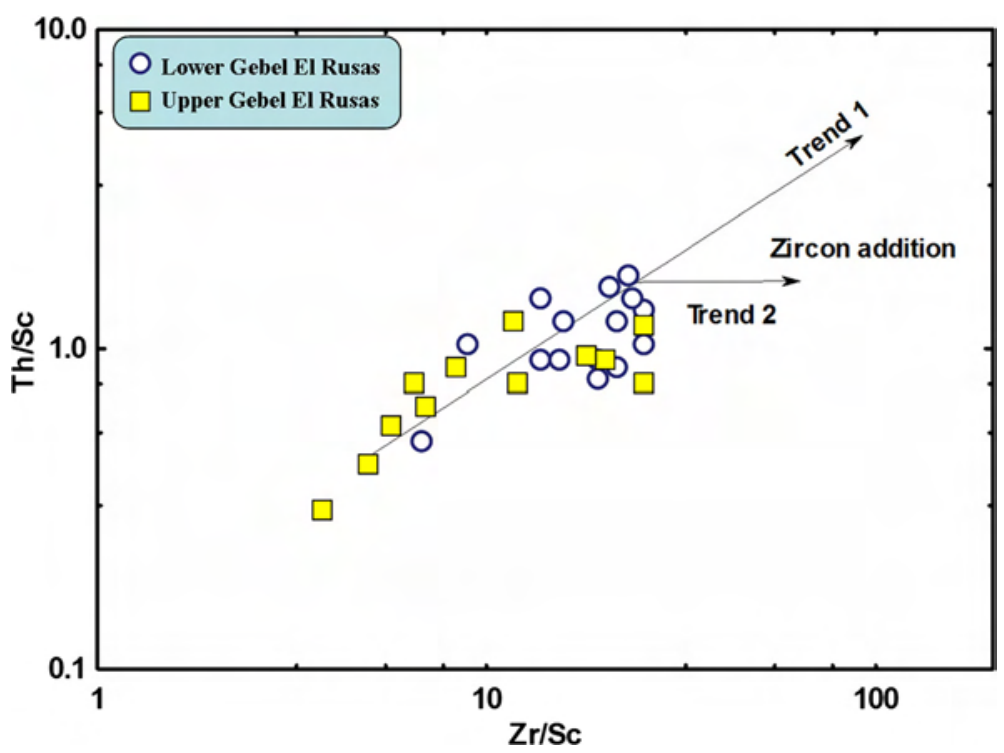

Figure 10. Th/Sc vs. Zr/Sc bivariate plot (McLennan et al. 1993). The accumulation of zircon due to sediment sorting and recycling is observed in trend 2 .

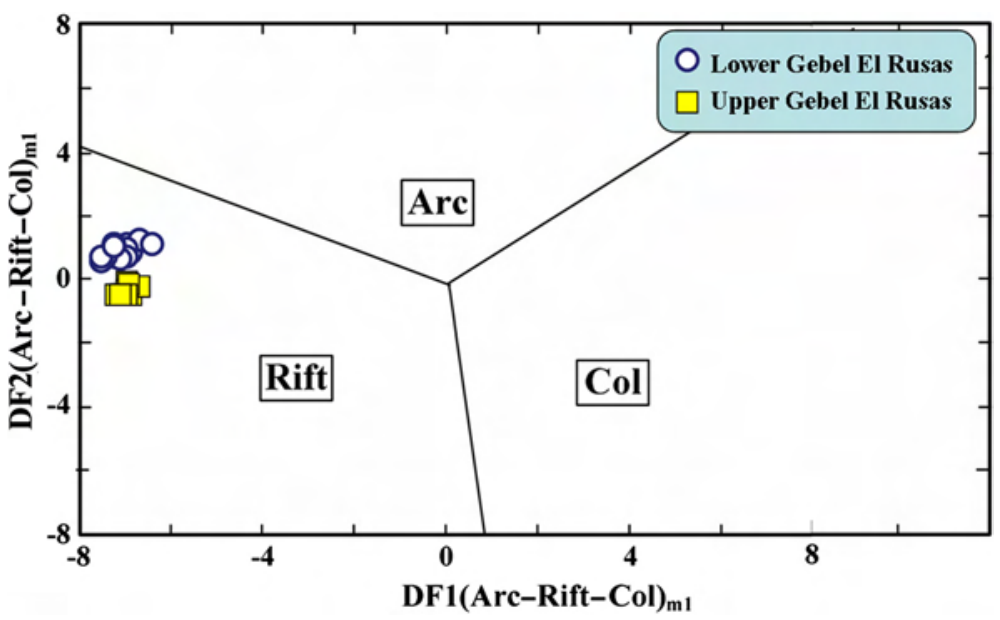

Figure 11. New discriminant-function multi-dimensional diagram proposed by Verma and Armstrong-Altrin (2013) for highsilica clastic sediments from three tectonic settings (arc, continental rift, and collision). The subscript m1 in DF1 and DF2 represents the high-silica diagram based on $\log _{e}$-ratios of major-elements. The discriminant function equations are:

$\mathrm{DF} 1_{(\mathrm{Arc}-\mathrm{Rift}-\mathrm{Col}) \mathrm{m} 1}=\left(-0.263 \times \operatorname{In}\left(\mathrm{TiO}_{2} / \mathrm{SiO}_{2}\right)_{\mathrm{adj}}\right)+\left(0.604 \times \operatorname{In}\left(\mathrm{Al}_{2} \mathrm{O}_{3} / \mathrm{SiO}_{2}\right)_{\mathrm{adj}}\right)+\left(-1.725 \times \operatorname{In}\left(\mathrm{Fe}_{2} \mathrm{O}_{3}^{t} / \mathrm{SiO}_{2}\right) \mathrm{adj}\right)+(0.660 \times$ $\left.\mathrm{In}\left(\mathrm{MnO} / \mathrm{SiO}_{2}\right)_{\mathrm{adj}}\right)+\left(2.191 \times \mathrm{In}\left(\mathrm{MgO} / \mathrm{SiO}_{2}\right)_{\mathrm{adj}}\right)+\left(0.144 \times \mathrm{In}\left(\mathrm{CaO} / \mathrm{SiO}_{2}\right)_{\mathrm{adj}}\right)+\left(-1.304 \times \operatorname{In}\left(\mathrm{Na}_{2} \mathrm{O} / \mathrm{SiO}_{2}\right) \mathrm{adj}\right)+(0.054 \times$ $\left.\mathrm{In}\left(\mathrm{K}_{2} \mathrm{O} / \mathrm{SiO}_{2}\right)_{\mathrm{adj}}\right)+\left(-0.330 \times \mathrm{In}\left(\mathrm{P}_{2} \mathrm{O}_{5} / \mathrm{SiO}_{2}\right) \mathrm{adj}\right)+1.588$.

$\mathrm{DF} 2_{(\mathrm{Arc}-\mathrm{Rift}-\mathrm{Col}) \mathrm{m} 1}=\left(-1.196 \times \mathrm{In}\left(\mathrm{TiO}_{2} / \mathrm{SiO}_{2}\right)_{\mathrm{adj}}\right)+\left(1.604 \times \mathrm{In}\left(\mathrm{Al}_{2} \mathrm{O}_{3} / \mathrm{SiO}_{2}\right)_{\mathrm{adj}}\right)+\left(0.303 \times \mathrm{In}\left(\mathrm{Fe}_{2} \mathrm{O}_{3}^{t} / \mathrm{SiO}_{2}\right)_{\mathrm{adj}}\right)+(0.436 \times$ $\left.\mathrm{In}\left(\mathrm{MnO} / \mathrm{SiO}_{2}\right)_{\mathrm{adj}}\right)+\left(0.838 \times \mathrm{In}\left(\mathrm{MgO} / \mathrm{SiO}_{2}\right)_{\mathrm{adj}}\right)+\left(-0.407 \times \mathrm{In}\left(\mathrm{CaO} / \mathrm{SiO}_{2}\right)_{\mathrm{adj}}\right)+\left(1.021 \times \mathrm{In}\left(\mathrm{Na}_{2} \mathrm{O} / \mathrm{SiO}_{2}\right)\right.$ adj $)+(-1.706 \times$ $\left.\mathrm{In}\left(\mathrm{K}_{2} \mathrm{O} / \mathrm{SiO}_{2}\right)_{\text {adj }}\right)+\left(-0.126 \times \mathrm{In}\left(\mathrm{P}_{2} \mathrm{O}_{5} / \mathrm{SiO}_{2}\right)_{\text {adj }}\right)-1.068$.

The tectonic setting discrimination diagrams proposed by Bhatia (1983) and Roser and Korsch (1986) for clastic sediments were used in many studies to identify the tectonic setting of unknown basins (Tobia and Aswad 2015; Zaid 2016). Many researchers cautioned against the use of these previously proposed discrimination diagrams (e.g., Armstrong-Altrin and Verma 2005; Ryan and Williams 2007). Recently, Verma and ArmstrongAltrin (2013) proposed two discriminant-functionbased major-element diagrams for the tectonic discrimination of siliciclastic sediments from three main tectonic settings; island or continental arc, continental rift and collision, that have been created for the tectonic discrimination of high-silica $\left(\left(\mathrm{SiO}_{2}\right)\right.$ adj $\left.=63-95 \%\right)$ and low-silica rocks $\left(\left(\mathrm{SiO}_{2}\right)\right.$ $\operatorname{adj}=35-63 \%)$. These diagrams were used in recent studies to discriminate the tectonic setting of a source region, based on sediment geochemistry (Armstrong-Altrin 2015, Armstrong-Altrin et al. 2016). According to the high-silica diagram (figure 11), all samples of the Lower and Upper 

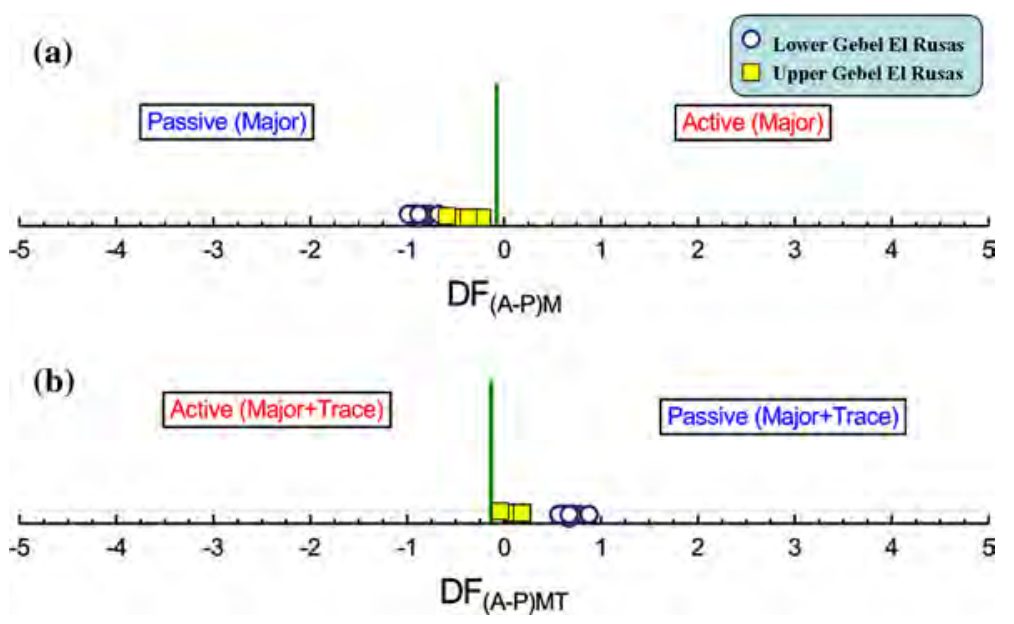

Figure 12. The new multi-dimensional discriminant function diagrams proposed by Verma Armstrong-Altrin (2016) for the discrimination of active (A) and passive (P) margin settings. (a) Major element (M) based diagram; (b) Combined major and trace element $(\mathrm{MT})$ based diagram. The discriminant function equations are:

(i) $\mathrm{DF}_{(\mathrm{A}-\mathrm{P}) \mathrm{M}}=\left(3.0005 \times \mathrm{ilr} 1_{\mathrm{TiM}}\right)+\left(-2.8243 \times \mathrm{ilr} 2_{\mathrm{AlM}}\right)+\left(-1.0596 \times \mathrm{ilr} 3_{\mathrm{FeM}}\right)+\left(-0.7056 \times \mathrm{ilr} 4_{\mathrm{MnM}}\right)+\left(-0.3044 \times \mathrm{ilr} 5_{\mathrm{MgM}}\right)+$ $\left(-0.6277 \times \mathrm{ilr} 6_{\mathrm{CaM}}\right)+\left(-1.1838 \times \mathrm{ilr} 7_{\mathrm{NaM}}\right)+\left(1.5915 \times \mathrm{ilr} 8_{\mathrm{KM}}\right)+\left(0.1526 \times \mathrm{ilr} 9_{\mathrm{PM}}\right)-5.9948$.

(ii) $\mathrm{DF}_{(\mathrm{A}-\mathrm{P}) \mathrm{MT}}=\left(3.2683 \times \mathrm{ilr} 1_{\mathrm{TiMT}}\right)+\left(5.3873 \times \mathrm{ilr} 2_{\mathrm{AlMT}}\right)+\left(1.5546 \times\right.$ ilr $\left.3_{\mathrm{FeMT}}\right)+\left(3.2166 \times \mathrm{ilr} 4_{\mathrm{MnMT}}\right)+\left(4.7542 \times \mathrm{ilr} 55_{\mathrm{MgMT}}\right)+$ $\left(2.0390 \times \mathrm{ilr} 6_{\mathrm{CaMT}}\right)+\left(4.0490 \times \mathrm{ilr} 7_{\mathrm{NaMT}}\right)+\left(3.1505 \times \mathrm{ilr} 8_{\mathrm{KMT}}\right)+\left(2.3688 \times \mathrm{ilr} 9_{\mathrm{PMT}}\right)+\left(2.8354 \times \mathrm{ilr} 10_{\mathrm{CrMT}}\right)+\left(0.9011 \times \mathrm{ilr} 11_{\mathrm{NbMT}}\right)+$ $\left(1.9128 \times \mathrm{ilr} 12_{\mathrm{NiMT}}\right)+\left(2.9094 \times \operatorname{lr} 13_{\mathrm{VMT}}\right)+\left(4.1507 \times \mathrm{ilr} 14_{\mathrm{YMT}}\right)+\left(3.4871 \times \mathrm{ilr} 15_{\mathrm{ZrMT}}\right)-3.2088$.

members of Gebel El Rusas sandstones are plotted exclusively within the rift field. The result obtained from this discriminant-function-based multi-dimensional diagram provides a good evidence for the Red Sea- Eastern Desert tectonic system, which is consistent with the general geology of Egypt (Said 1990).

In addition, recently, Verma Armstrong-Altrin (2016) also proposed two new discriminant-function-based multidimensional diagrams for the discrimination of active and passive margin settings. On these plots (figure 12a, b), the samples exclusively plot in the passive margin field. The results obtained from these discriminant function diagrams are consistent with the regional geology of the Red Sea Coastal plain and Eastern Desert of Egypt during the Middle Miocene (Purser and Philobbos 1993).

\section{Conclusions}

The Middle Miocene Gebel El Rusas Formation consists of two members. The Lower Member is typically irregularly bedded, poorly sorted and heterogeneous. A conglomerate bed of large granitic boulders separates this member from the underlying basement rocks. The Lower Member is formed mainly of sandstones, conglomerates with clay interbeds. The sandstones are varicoloured and enriched in feldspar gains. The Upper Member is more calcareous and formed mainly of sandstones and limestones with marls and clays intercalations. The provenance of the Middle Miocene Gebel El Rusas sandstones has been assessed using integrated geochemical and petrographical data. The Lower Member sandstones are arkoses and derived from transitional continental provenance, while the Upper Member sandstones are subarkoses and derived from cratonic interior.

The $\mathrm{CIA}$ and $\mathrm{Rb} / \mathrm{Sr}$ ratio values and $\mathrm{A}-\mathrm{CN}-\mathrm{K}$ diagram suggest that the source rocks of Gebel El Rusas sandstones could be weathered crystalline granitic source terrain. Also, the ICV and $\mathrm{SiO}_{2} / \mathrm{Al}_{2} \mathrm{O}_{3}$ ratio values and $\mathrm{Th} / \mathrm{Sc}$ vs. $\mathrm{Zr} / \mathrm{Sc}$ diagram of Gebel El Rusas sandstones suggest first-cycle deposits, moderate weathering and low maturity.

$\mathrm{Th} / \mathrm{Sc}, \mathrm{Th} / \mathrm{Co}, \mathrm{Th} / \mathrm{Cr}, \mathrm{Rb} / \mathrm{Sr}, \mathrm{Al}_{2} \mathrm{O}_{3} / \mathrm{TiO}_{2}$ and $\mathrm{K}_{2} \mathrm{O} / \mathrm{Na}_{2} \mathrm{O}$ ratios for the Gebel El Rusas sandstones in both studied sections received a major contribution from felsic rocks. In addition, these sandstones are largely depleted on $\mathrm{Cr}$ and $\mathrm{Ni}$ contents, indicating limited contribution of intermediate rocks in the source area. The chemical characteristics and tectonic discriminant-function diagrams suggest that the Gebel El Rusas sandstones were deposited on a passive continental margin of a synrift basin that received large amounts of mature detritus from the hinterland 
areas. The Proterozoic granites situated on the western side of study area are the potential source rocks for the Gebel El Rusas sandstones, which have been uplifted and exposed by the Rifting Orogeny (Oligocene-post Miocene).

\section{Acknowledgements}

The author thanks members of the laboratory of the National Research Center of Egypt for facilitating analytical work for the present research. Thanks are also due to the journal reviewers, for their very constructive and helpful comments as well as for editorial comments, which helped to improve the manuscript.

\section{References}

Abu-Zeid M M, Amer K M and El-Mohammady R A 1989 Petrology, mineralogy and provenance of sandstones of 'Nubia' facies in west central Sinai; Earth Sci. Ser. 3. Middle East Research Centre, Ain Shams University, Cairo, pp. 20-34.

Abu-Zeid M M, Amer K M, Yanni N N and El-Wekeil S S 1991 Petrology, mineralogy and sedimentation of the Paleozoic sequence of Gabal Qattar, Wadi Feiran, Sinai, Egypt; J. Geol. 34 145-169.

Ahmedali S T 1989 X-ray fluorescence analysis in the geological sciences; Advances in Methodology, Geological Association of Canada, 7 308p.

Akarish A I M and El-Gohary A M 2008 Petrography and geochemistry of lower Paleozoic sandstones East Sinai, Egypt: Implications for provenance and tectonic setting; J. Afr. Earth Sci. 52 43-54.

Amer K M, Abu-Zeid M M and El-Mohammady R A 1989 Particle-size distribution and depositional environment of the sandstones of "Nubia" facies in west central Sinai; Earth Sci. Ser. 3, Middle East Research Centre, Ain Shams University, Cairo, pp. 146-160.

Armstrong-Altrin J S 2015 Evaluation of two multidimensional discrimination diagrams from beach and deep-sea sediments from the Gulf of Mexico and their application to Precambrian clastic sedimentary rocks; Int. Geol. Rev. 57 1444-1459.

Armstrong-Altrin J S and Verma S P 2005 Critical evaluation of six tectonic setting discrimination diagrams using geochemical data of Neogene sediments from known tectonic setting; Sedim. Geol. 177 115-129.

Armstrong-Altrin J S, Lee Y I, Verma S P and Ramasamy S 2004 Geochemistry of sandstones from the Upper Miocene Kudankulam Formation, southern India: Implications for provenance, weathering, and tectonic setting; J. Sedim. Res. 74 285-297.

Armstrong-Altrin J S, Lee Y I, Kasper-Zubillaga J J, Carranza-Edwards A, Garcia D, Eby N, Balaram V and Cruz-Ortiz N L 2012 Geochemistry of beach sands along the western Gulf of Mexico, Mexico: Implication for provenance; Chem. Erde/Geochem. 72 345-362.

Armstrong-Altrin J S, Nagarajan R, Madhavaraju J, Rosalez-Hoz L, Lee Y I, Balaram V, Cruz-Martinez A and Avila-Ramirez G 2013 Geochemistry of the Jurassic and upper Cretaceous shales from the Molango Region, Hidalgo, Eastern Mexico: Implications of source-area weathering, provenance, and tectonic setting; Comptes Rendus Geosci. 345 185-202.

Armstrong-Altrin J S, Machain-Castillo M L, Rosales-Hoz L, Carranza-Edwards A, Sanchez-Cabeza J A and RuízFernández A C 2015a Geochemistry of deep sea sediments from the south-western Gulf of Mexico, Mexico: Implication for depositional environment; Cont. Shelf Res., doi: 10.1016/j.csr.2015.01.003.

Armstrong-Altrin J S, Nagarajan R, Balaram V and Natalhy-Pineda O 2015b Petrography and geochemistry of sands from the Chachalacas and Veracruz beach areas, western Gulf of Mexico, Mexico: Constraints on provenance and tectonic setting; J. South Am. Earth Sci. 64 199-216.

Armstrong-Altrin J S, Lee Y I, Kasper-Zubillaga J J and Trejo-Ramirez E 2016 Mineralogy and geochemistry of sands along the Manzanillo and El Carrizal beach areas, southern Mexico: Implication for palaeoweathering, provenance, and tectonic setting; Geol. J., doi: 10.1002/gj.2792.

Basu A, Young S, Suttner L J, James W C and Mack C H 1975 Re-evaluation of the use of undulatory extinction and polycrystallinity in detrital quartz for provenance interpretation; J. Sedim. Petrol. 45 873-882.

Bhatia M R 1983 Plate tectonics and geochemical composition of sandstones; J. Geol. 91 611-627.

Bhatia M R and Crook K A W 1986 Trace element characteristics of greywackes and tectonic setting discrimination of sedimentary basins; Contrib. Mineral. Petrol. 92 181-193.

Blatt H, Middleton G and Murray R 1980 Origin of sedimentary rocks; Prentice-Hall, New Jersey.

Conoco 1987 Geological map of Egypt (scale 1:500,000), NG 36 SE Gebel Hamata.

Cox R, Lowe D R and Cullers R L 1995 The influence of sediment recycling and basement composition on evolution of mudrock chemistry in the southwestern United States; Geochim. Cosmochim. Acta 59 2919-2940.

Cullers R L 1994 The controls on the major and trace element variation of shales, siltstones, and sandstones of Pennsylvanian-Permian age from uplifted continental blocks in Colorado to platform sediment in Kansas, USA; Geochim. Cosmochim. Acta 58 4955-4972.

Cullers R L 2000 The geochemistry of shales, siltstones and sandstones of Pennsylvanian-Permian age, Colorado, USA: Implications for provenance and metamorphic studies; Lithos 51 181-203.

Cullers R L and Podkovyrov V N 2000 Geochemistry of the Mesoproterozoic Lakhanda shales in southeastern Yakutia, Russia: Implications for mineralogical and provenance control, and recycling; Precamb. Res. 104 77-93.

Davis J C 1986 Statistics and data analysis in Geology; John Wiley \& Sons. Inc., New York.

Dickinson W R 1970 Interpreting detrital modes of greywacke and arkose; J. Sedim. Petrol. 40 695-707.

Dickinson W R, Beard L S, Brakenridge G R, Erjavec J L, Ferguson R C, Inman K F, Knepp R A, Lindberg F A and 
Ryberg P T 1983 Provenance of North American Phanerozoic sandstones in relation to tectonic setting; Geol. Soc. Am. Bull. $94222-235$.

Dott R H 1964 Wackes, greywacke and matrix: What approach to immature sandstone classification; J. Sedim. Petrol. 34 625-632.

El-Akkad S and Dardir A A 1966 Geology of the Red Sea Coast between Ras Shagra and Mersa Alam with short notes on results of exploratory work at Gabal EI-Rusas lead-zinc deposits; Geol. Surv. Egypt 35 1-67.

Etemad-Saeed N, Hosseini-Barzi M and Armstrong Altrin J S 2011 Petrography and geochemistry of clastic sedimentary rocks as evidences for provenance of the Lower Cambrian Lalun Formation, Posht-e-badam block, Central Iran; J. Afr. Earth Sci. 61 142-159.

Etemad-Saeed N, Hosseini-Barzi M, Edabi M H, Sadeghi A and Houshmandzadeh A 2015a Provenance of Neoproterozoic sedimentary basement of northern Iran, Kahar Formation; J. Afr. Earth Sci. 111 54-75.

Etemad-Saeed N, Hosseini-Barzi M, Edabi M H, Miller N R, Sadeghi A, Houshmandzadeh A and Stockli D F 2015b Evidence for Ca. 560 Ma Ediacaran glaciation in the Kahar formation, Central Alborz Mountains, northern Iran; Gondwana Res., doi: 10.1016/d.gr2015.01.005.

Garver J I, Royce P R and Smick T A 1996 Chromium and nickel in shale of the Taconic Foreland: A case study for the provenance of fine-grained sediments with an ultramafic source; J. Sedim. Res. 66 100-106.

Gazzi P 1966 Le arenarie del fl ysch sopracretaceo dell'Appennino modensese: Correlazioni con il fl ysch di Monghidoro; Mineral. Petrogr. Acta 12 69-97.

Ingersoll R V, Bulard T F, Ford R L, Grimn J P, Pickle J $\mathrm{P}$ and Sares S W 1984 The effect of grain size on detrital modes: A text of the Gazzi-Dickinson Point Counting method; J. Sedim. Petrol. 54 103-116.

Issawi B, Francis M H, Youssef E A A and Osman R A 2009 The Phanerozoic geology of Egypt, a geodynamic approach; 2nd edn, The Egyptian Mineral Resources Authority, 81 589p.

Keller W D 1956 Clay minerals as influenced by environments of their formation; Am. Assoc. Petrol. Geol. 40 2689-2710.

Kora M and Abdel-Fattah Z 2000 Pliocene and PlioPleistocene macrofauna from the Red Sea coastal plain (Egypt): Biostratigraphy and biogeography; Geol. Palaeontol. 34 219-235.

Liu B, Jin H L, Sun Z, Niu Q H and Zhang C X 2015 Geochemical characteristics of Holocene Aeolian deposits and their environmental significance in the $\mathrm{Mu}$ Us desert, northern China; Geol. J., doi: 10.1002/gj.2630.

Lonnie T P 1982 Mineralogic and chemical composition of marine and non-marine transitional clay beds on south shore of Long Island, New York; J. Sedim. Petrol. 52529 536.

Lozano R and Bernal JP 2005 Characterization of a new set of eight geochemical reference materials for XRF major and trace element analysis; Rev. Mex. Cien. Geol. 22 329-344.

Madhavaraju J 2015 Geochemistry of Late Cretaceous sedimentary rocks of the Cauvery Basin, south India: Constraints on paleoweathering, provenance and end Cretaceous environments; In: Chemostratigraphy: Concepts, techniques and applications (ed.) Ramkumar M, Elsevier, The Netherlands, 1st edn, pp. 185-214.

McBride E F 1963 A classification of common sandstones; J. Sedim. Petrol. 33 664-669.

McLennan S M, Taylor S R and Eriksson K A 1983 Geochemistry of Archaean shales from the Pilbara Supergroup, western Australia; Geochim. Cosmochim. Acta 47 12111222 .

McLennan S M, Hemming S, McDaniel D K and Hanson G N 1993 Geochemical approaches to sedimentation, provenance, and tectonics; In: Processes controlling the composition of clastic sediments (eds) Johnsson M J and Basu A; Geol. Soc. Am. Spec. Paper, pp. 21-40.

Migani F, Borghesi F and Dinelli E 2015 Geochemical characterization of surface sediments from the northern Adriatic wetlands around the Po river delta, Part 1: Bulk composition and relation to local background; $J$. Geochem. Explor. 156 72-88.

Nagarajan R, Armstrong-Altrin J S, Kessler F L, HidalgoMoral E L, Dodge-Wan D and Taib N I 2015 Provenance and tectonic setting of Miocene siliciclastic sediments, Sibuti Formation, northwestern Borneo; Arab. J. Geosci. 8(10) 8549-8565.

Nesbitt H W and Young G M 1982 Early Proterozoic climates and plate motions inferred from major element chemistry of lutites; Nature 299 715-717.

Nesbitt H W and Young G M 1984 Prediction of some weathering trends of plutonic and volcanic rocks based on thermodynamic and kinetic considerations; Geochim. Cosmochim. Acta 48 1523-1534.

Odoma A N, Obaje N G, Omado J I, Idakwo S O and Erbacher J 2015 Mineralogical, chemical composition and distribution of rare earth elements in clay-rich sediments from southeastern Nigeria; J. Afr. Earth Sci. 102 $50-60$.

Osae S, Asiedu D K, Banoeng-Yakubo B, Koeberl C and Dampare S B 2006 Provenance and tectonic setting of Late Proterozoic Buem sandstones of southeastern Ghana: Evidence from geochemistry and detrital modes; J. Afr. Earth Sci. 44 85-96.

Potter P E 1978 Petrology and chemistry of modern Big River sands; J. Geol. 86 423-449.

Purser B and Philobbos E 1993 The sedimentary expressions of rifting in the NW Red Sea, Egypt; Geol. Soc. Am. Spec. Paper 1 1-46.

Rahman M J J, Sayem A S M and McCann T 2014 Geochemistry and provenance of the Miocene sandstones of the Surma Group from the Sitapahar anticline, southeastern Bengal Basin, Bangladesh; J. Geol. Soc. India 83 447456.

Roser B P, Cooper R A, Nathan S A and Tulloch A J 1996 Reconnaissance sandstone geochemistry, provenance, and tectonic setting of the lower Paleozoic terrains of the West Coast and Nelson, New Zealand; New Zealand J. Geol. Geophys. 39 1-16.

Roser B P and Korsch R J 1986 Determination of tectonic setting of sandstone-mudstone suites using $\mathrm{SiO}_{2}$ content and $\mathrm{K}_{2} \mathrm{O} / \mathrm{Na}_{2} \mathrm{O}$ ratio; J. Geol. 94 635-650.

Roser B P and Korsch R J 1988 Provenance signatures of sandstone-mudstone suites determined using discrimination function analysis of major element data; Chem. Geol. 67 119-139. 
Ryan K M and Williams D M 2007 Testing the reliability of discrimination diagrams for determining the tectonic depositional environment of ancient sedimentary basins; Chem. Geol. 242 103-125.

Said R 1990 The geology of Egypt; Balkema, Rotterdam, $734 \mathrm{p}$.

Sharma A, Sensarma S, Kumar K, Khanna P P and Saini N K 2013 Mineralogy and geochemistry of the Mahi River sediments in tectonically active western India: Implications for Deccan large igneous province source, weathering and mobility of elements in a semi-arid climate; Geochim. Cosmochim. Acta 104 63-83.

Tawfik H A, Ghandour I M, Maejima W, Armstrong-Altrin J S and Abdel-Hameed A M T 2015 Petrography and geochemistry of the siliciclastic Araba Formation (Cambrian), east Sinai, Egypt: Implications for provenance, tectonic setting and source weathering; Geol. Mag., doi: 10.1017/S0016756815000771.

Taylor S R and McLennan S M 1985 The continental crust: Its composition and evolution; Oxford, UK: Blackwell.

Tobia F H and Aswad K J 2015 Petrography and geochemistry of Jurassic sandstones, Western Desert, Iraq: Implications on provenance and tectonic setting; Arab. J. Geosci. 8(5) 2771-2784.

Tsuzuki Y and Kawabe I 1983 Polymorphic transformations of kaolin minerals in aqueous solutions; Geochim. Cosmochim. Acta 47 59-66.

Corresponding editor: PARTha Pratim Chakraborty
Vdačný M, Vozarova A and Vozar J 2013 Geochemistry of the Permian sandstones from the Maluz-ina Formation in the Male Karpaty Mts (Hronic Unit, Western Carpathians, Slovakia): Implications for source-area weathering, provenance and tectonic setting; Geol. Carpath. $6423-$ 38.

Verma S P and Armstrong-Altrin J S 2013 New multidimensional diagrams for tectonic discrimination of siliciclastic sediments and their application to Precambrian basins; Chem. Geol. 355 117-180.

Verma S P and Armstrong-Altrin J S 2016 Geochemical discrimination of siliciclastic sediments from active and passive margin settings; Sedim. Geol. 332 1-12.

Verma S P, Diaz-Gonzalez L and Armstrong-Altrin J S 2015 Application of a new computer program for tectonic discrimination of Cambrian to Holocene clastic sediments; Earth Sci. Inf., doi: 10.1007/s12145-015-0244-0.

Zaid S M 2002 Geo-environmental study of north Marsa Alam, Red Sea, Egypt; M.Sc. thesis, Zagazig Univ., Egypt, 280p.

Zaid S M 2015a Geochemistry of sandstones from the Pliocene Gabir Formation, north Marsa Alam, Red Sea, Egypt: Implication for provenance, weathering and tectonic setting; J. Afr. Earth Sci. 102 1-17.

Zaid S M 2016 Geochemistry of shales from the Upper Miocene Samh Formation, north Marsa Alam, Red Sea, Egypt: Implications for source area weathering, provenance, and tectonic setting; Arab. J. Geosci. 9593. 